\title{
جمع القرآن \\ ورد الشبهات حوله
}

\author{
كلهِ إعداد الدكتور \\ صالح بن أحمد بن عبيد العلوي
}

أستاذ الكتاب والسنة المساعد بقسم الشريعة والدراسات إلسائلية إلهدية

كلية الآداب والعلوم الإنسانية. جامعة الملك عبدالعزيز - جدة 


\section{جمع القرآن ورد الشبهات حوله}

\section{صالح بن أحمد بن عبيد العلوي}

قسم الكتاب والسـنة ـ قسـم الشـريعة والدراسـات إلسـاليلية ـ كليـة الآداب والعلـوم . . . . الإنسانيةـ جامعة الملك عبدالعزيز - جدة - السعودية .

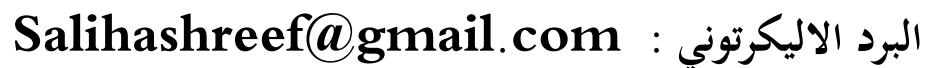
الملخص: البرد الخكتر

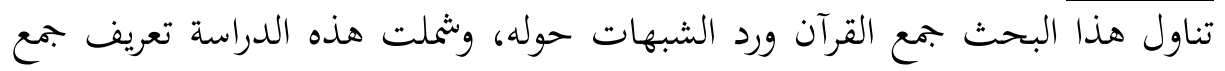

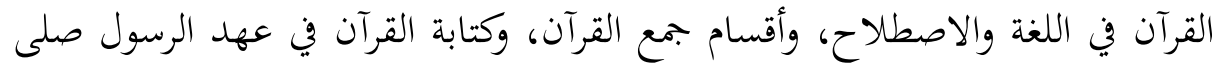

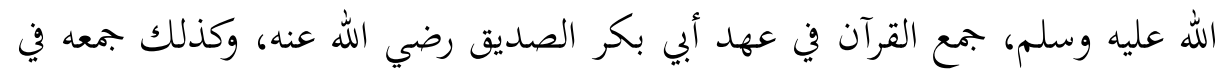

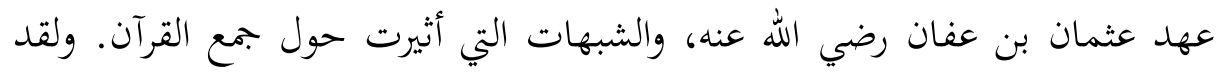

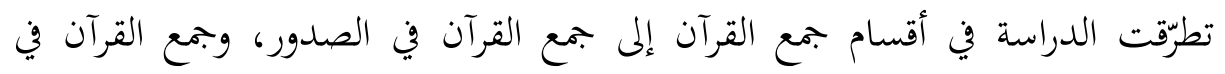

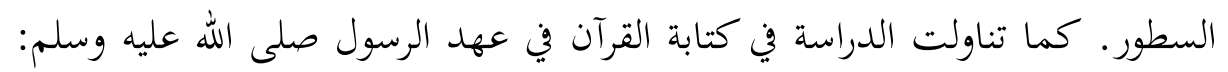

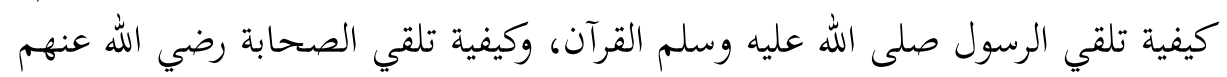

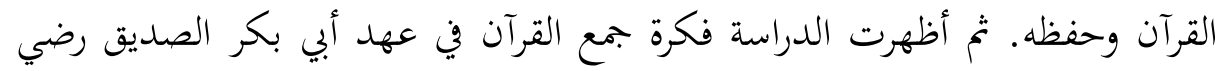

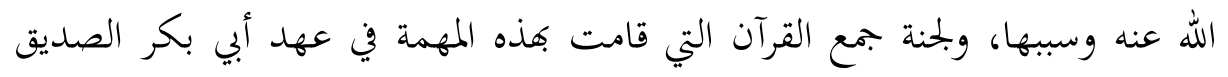

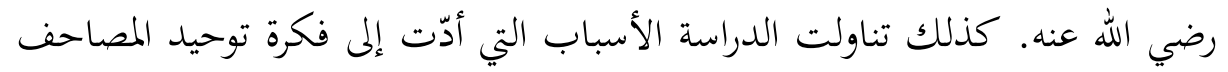

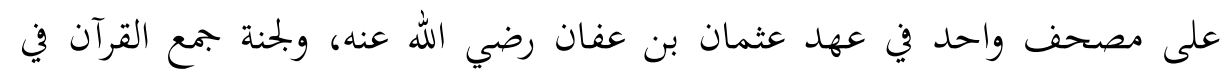

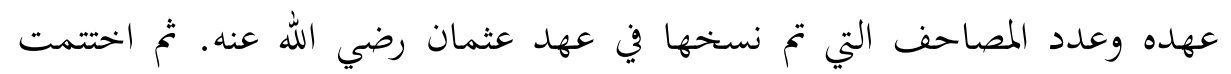

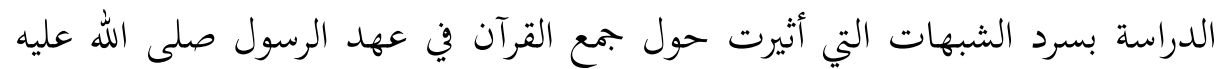

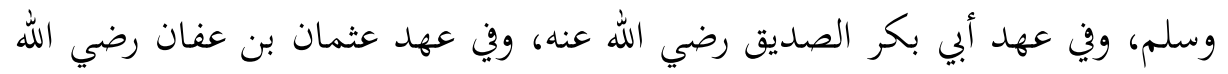
عنه، والرد عليها جميعا. الكلمات المفتاحية : جمع القرآن - كتابة القرآن - الشبهات - ردها . 


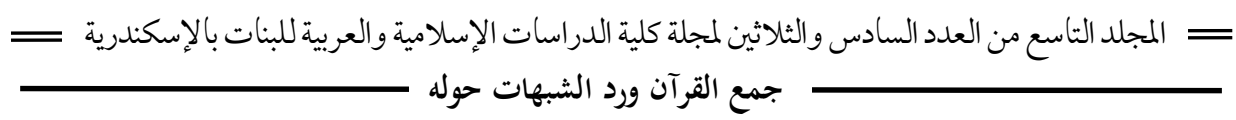

\section{Collect the Qur'an and respond to suspicions about it}

Saleh bin Ahmed bin Obaid Al-Alawi

Department of the Book and Sunnah - Department of Sharia and Islamic Studies - College of Arts and Humanities - King Abdulaziz University - Jeddah - Saudi Arabia.

\section{e-mail: Salihashreef@gmail.com \\ abstract:}

This research dealt with collecting the Qur'an and rejecting suspicions about it. This study included defining the collection of the Qur'an in language and convention, sections of the collection of the Qur'an, writing the Qur'an in the era of the Messenger, may God bless him and grant him peace, the collection of the Qur'an during the reign of Abu Bakr AlSiddiq, may God be pleased with him, and also collecting it during the reign of Othman bin Affan, may God be pleased with him, and the suspicions that were raised about the collection of the Qur'an. In the sections of Qur'an collection, the study dealt with collecting the Qur'an in the texts, and collecting the Qur'an in the lines. The study also dealt with writing the Qur'an during the era of the Messenger, may God bless him and grant him peace: How the Messenger, may God's prayers and peace be upon him, received the Qur'an, and how the Companions, may God be pleased with them, received the Qur'an and memorized it. Then the study revealed the idea of collecting the Qur'an during the reign of Abu Bakr Al-Siddiq May God be pleased with him and its 


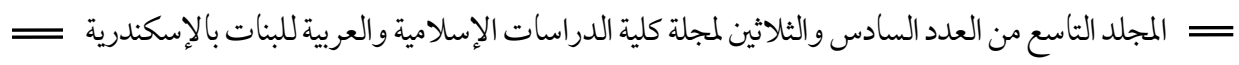
جمع القرآن ورد الشبهات حوله

reason, and the Qur'an Collection Committee, which carried out this task during the reign of Abu Bakr Al-Siddiq, may God be pleased with him. The study also dealt with the reasons that led to the idea of unifying the Qur'ans on a single Qur'an during the reign of Othman bin Affan, may God be pleased with him, the Qur'an Collection Committee during his reign, and the number of copies that were copied during the reign of Uthman, may God be pleased with him. Then the study concluded by listing the suspicions that were raised about the collection of the Qur'an during the era of the Messenger, may God bless him and grant him peace, and during the reign of Abu Bakr Al-Siddiq, may God be pleased with him, and during the reign of Othman bin Affan, may God be pleased with him, and responding to them all.

Keword: Collection of the Qur'an - Writing the Qur'an Suspicions - Reply.

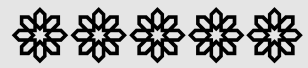


الحمد لله وحده، والصلاة والسلام على نبيه محمد وعلى آله وصحبه أجمعين.

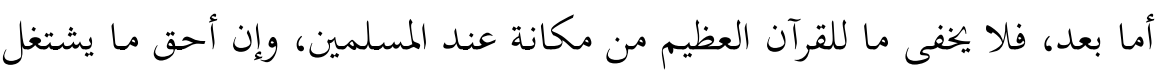

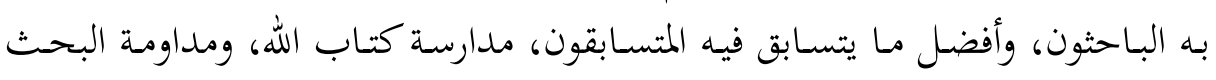

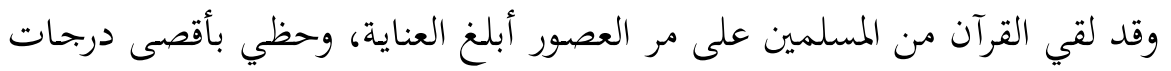

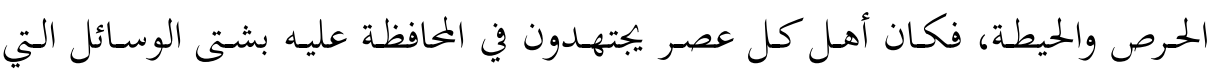

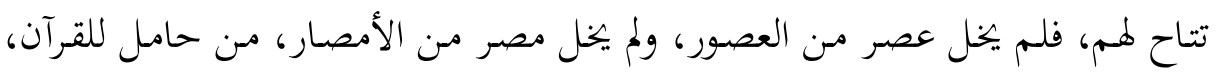

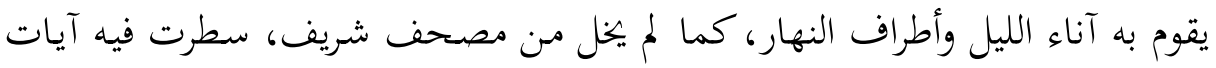
القرآن، وحفظت من التحريف.

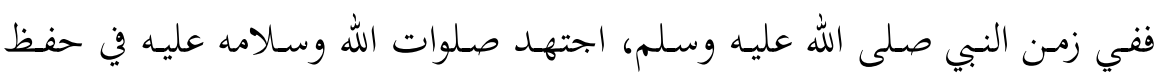

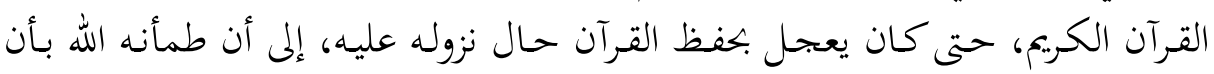

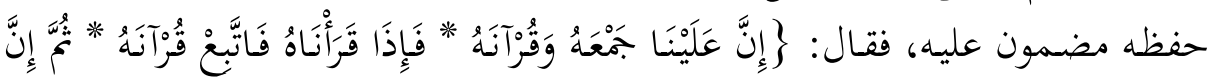

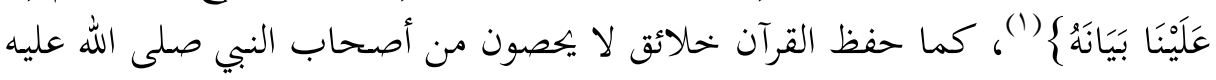
وسلم.

وفي ذلك العصر دوّن القرآن الكريم بين يدي النبي صلى الله عليه وسلم، فكان النهان

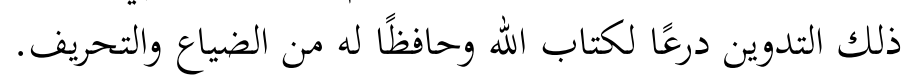

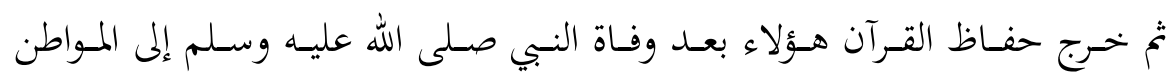

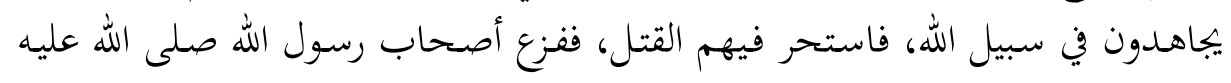




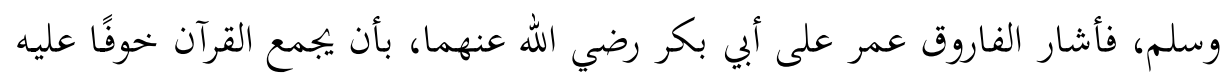

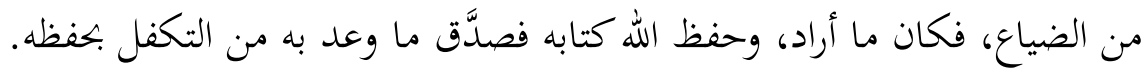

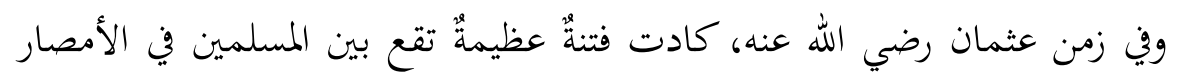

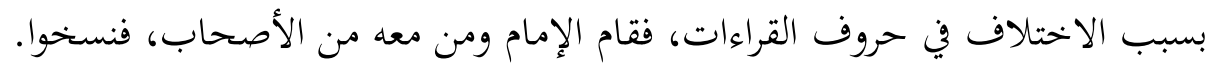

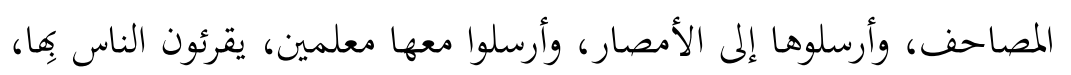

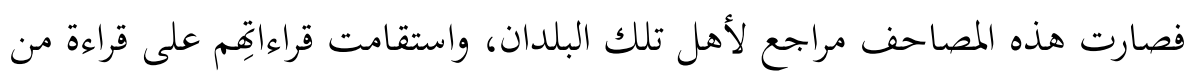
أرسل إليهم من القراء.

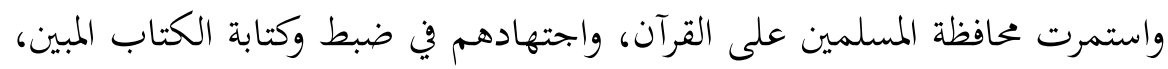

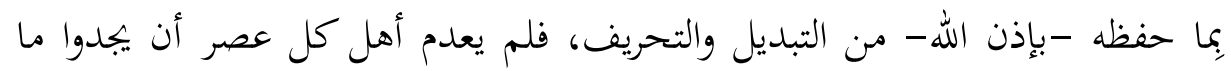
يبذلونه في سبيل حفظ كتاب الله، حتى صار المسلمون على مرٍّ الزمان مشاركين جمعيًا

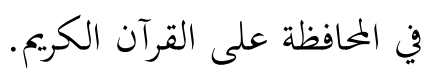

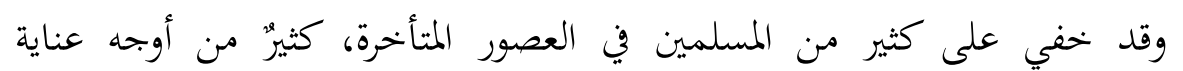

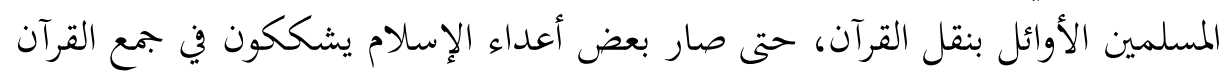

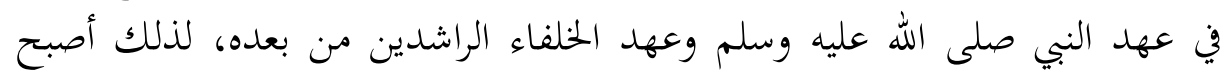

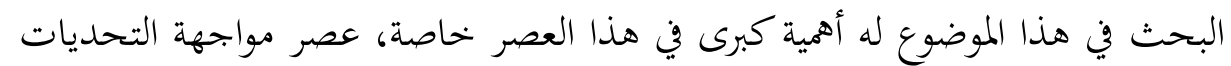
وصراع العقائد والأفكار، والحرب على لـ الإسلام والمسلمين قائمة على فلى قدم وساق.

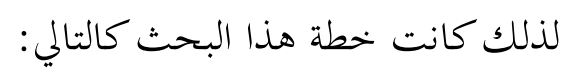

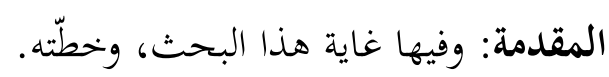

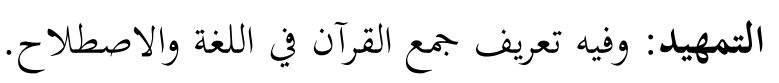
المبحث الأول: أقسام جمع القرآن.

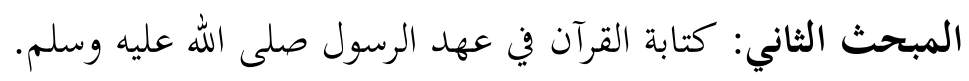

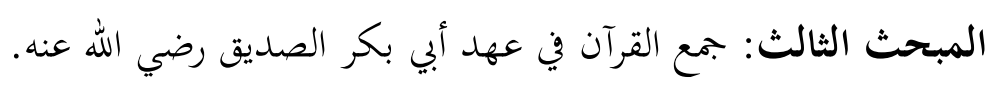

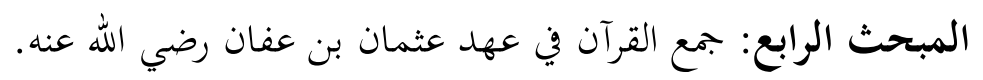
المبحث الخامس: الشبهات حول جمع القرآن.

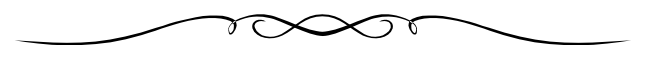




\section{التمهيد}

\section{تعريف جمع القرآن في اللغة:}

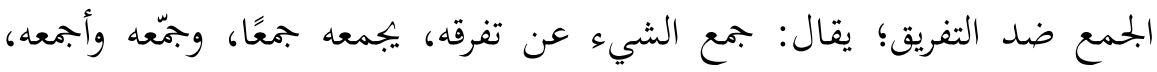

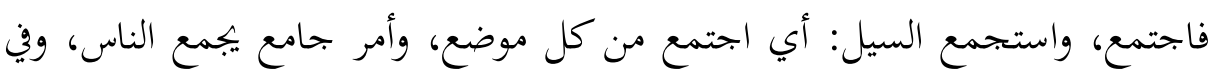

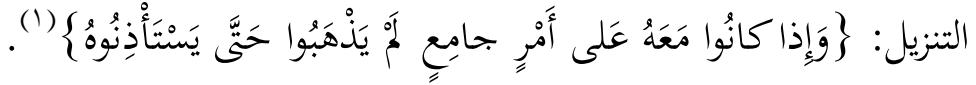

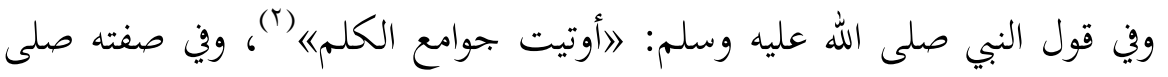

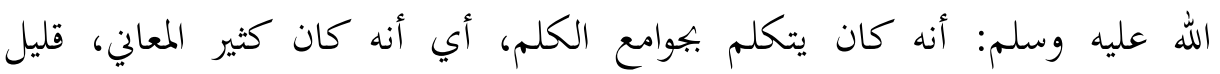

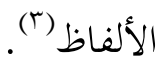

\section{تعريف جمع القرآن في الاصطلاح:}

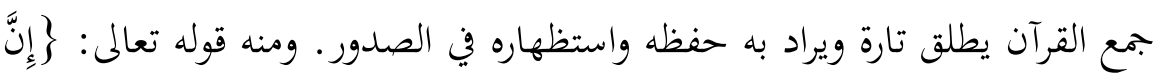

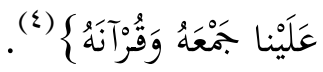

ويطلق تارة أخرى ويراد به كتابته كله؛ حروفًا وكلماتٍ وآياتٍ وسورًا، وهو جمعه في وحرانه

(0) السطور (ن)

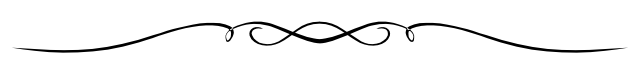

(1) سورة النور: الآية (TT).

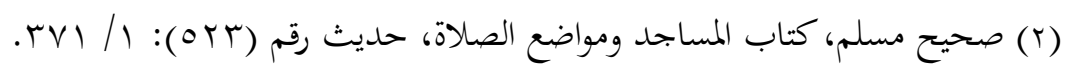

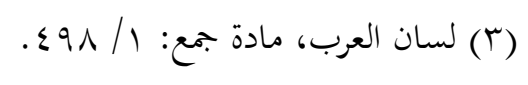

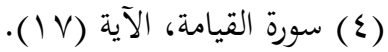

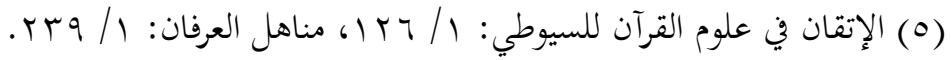




\section{المبحث الأول}

\section{أقسام جمع القرآن}

$$
\text { أولًا: جمع القرآن في الصدور. }
$$

كان الصحابة رضي الله عنهم من قوم قد تمرنوا على الحفظ عبر مئات السنين، وكانوا يفتخرون بقوة حافظتهم، وجودة ملكتهم.

فالذين حفظوا القرآن من الصحابة كانوا كثيرين حتى بلغ عدد القتلى منهم في بئر

$$
\text { معونة ويوم اليمامة مائة وأربعين (1). }
$$

والاعتماد في نقل القرآن على حفظ القلوب والصدور لا على حفظ المصاحف والكتب، يعد أشرف خصيصة من الله تعالى لمذه الأمة، فجاء في الحديث أن النبي صلى الله عليه وسلم قال: اإن ربي قال لي: قم في قريش فأنذرهم، فقلت له: رب إذن يثلغوا رأسي حتى يدعوه خبزة، فقال: إني مبتليك ومبتل بك ومنزل عليك كتابا لا لا يغسله الماء تقرأه نائما ويقظانا، فابعث جندا أبعث مثلهم وقاتل بمن أطاعك من عصاك، وأنفق من ينفق عليك» (r). فأخبر تعالى أن القرآن لا يحتاج في حفظه إلى صحيفة تغسل بالماء، بل يقرأ في كل حال، وذلك بخلاف أهل الكتاب الذين لا يحفظونه إلا في الكتب ولا يقرءونه كله إلا نظرا لا عن ظهر قلب (َ).

$$
\text { (1) النشر في القراءات العشر لابن الجزري: 1/ / ؟. }
$$

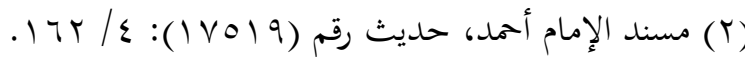

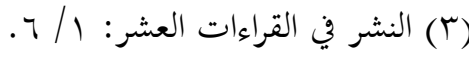


ثانيًا: جمع القرآن في السطور.

لقد ظل الاهتمام بحفظ القرآن الكريم في عهد الرسول صلى الله عليه وسلم مرافقًا

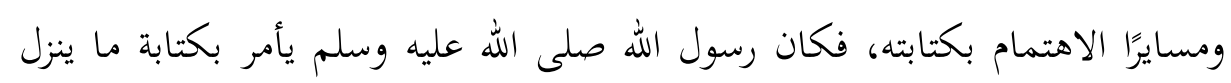

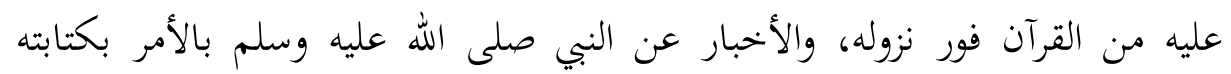

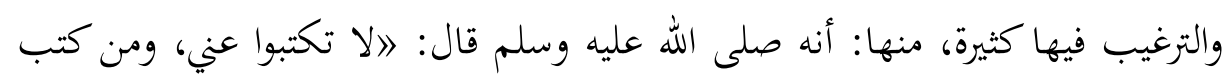

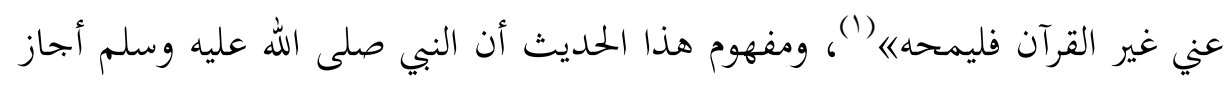

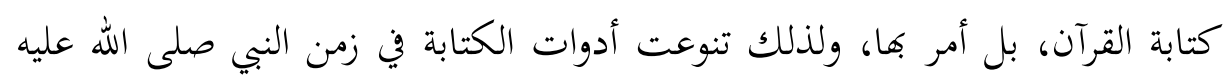

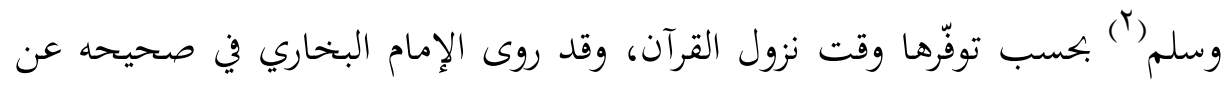

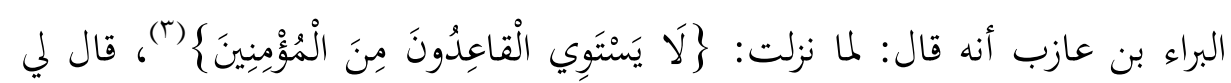

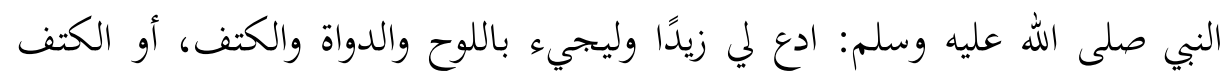

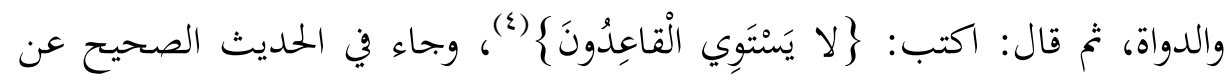

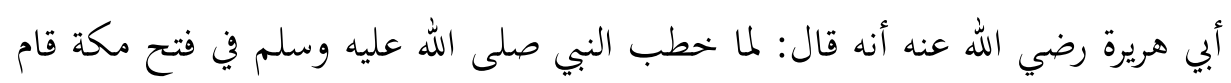

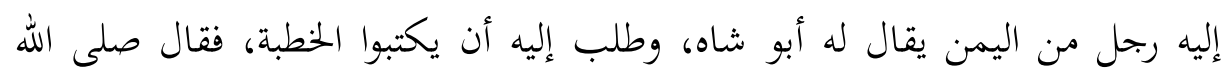

\footnotetext{
(1) صحيح مسلم، كتاب الزهد والرقائق، باب التثبت في الحديث وحكم كتابة العلم، حديث رقم

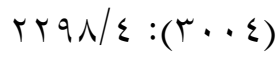

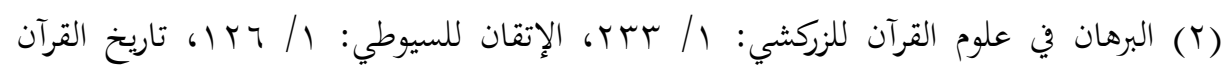

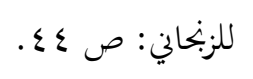

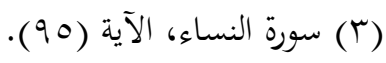

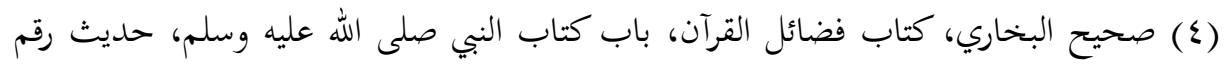

$$
.19 \cdot 9 / \varepsilon:(\varepsilon \nabla \cdot \varepsilon)
$$




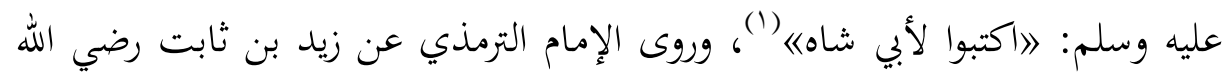

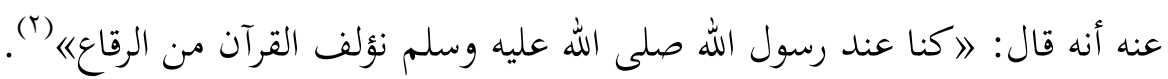
وهكذا كان رسول الله صلى الله عليه وسلم إذا نزل عليه شيء من القرآن يدعو

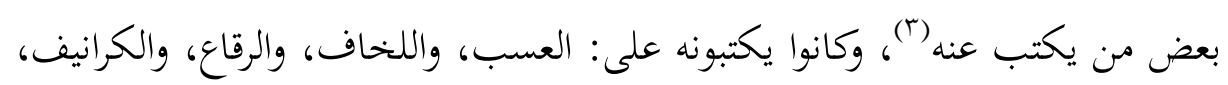
وقطع الأديم، وعظام الأكتاف، والأضلاع، والأقتاب (s). وقد ورد في قصة إسلام عمر بن الخطاب رضي الله عنهم أن أوائل سورة (طه)

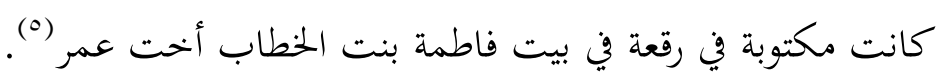

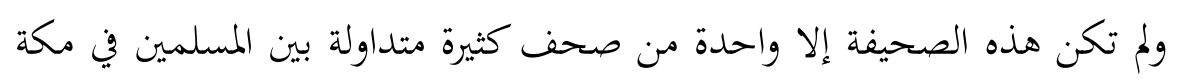
يقروون فيها القرآن. وهكذا فقد ظل القرآن يكتب في حياة رسول الله صلى الله عليه وسلم على القطع

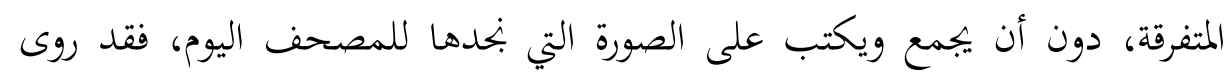

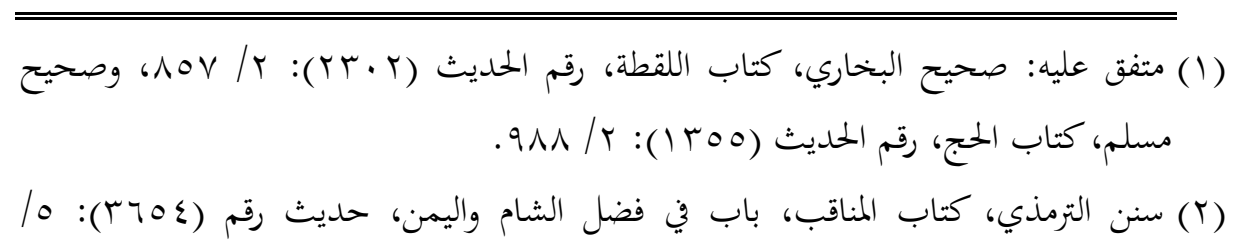
.VT

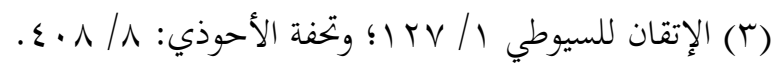

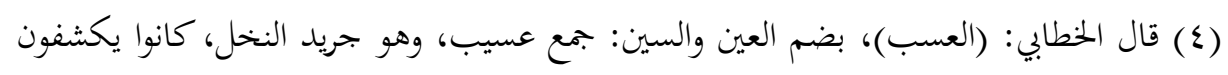
الخوص ويكتبون في الطرف العريض. و (اللخاف)، بكسر اللام: جمع لخفة، وهي صفائح

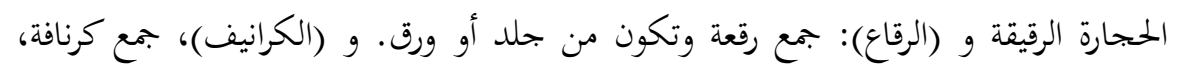

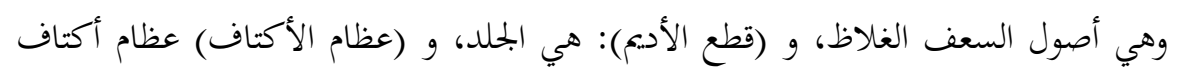

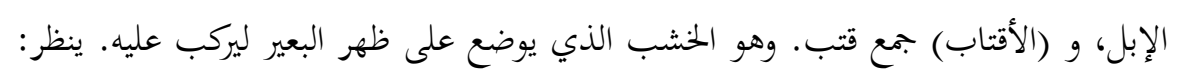

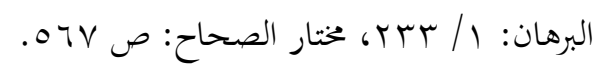

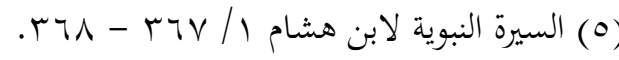




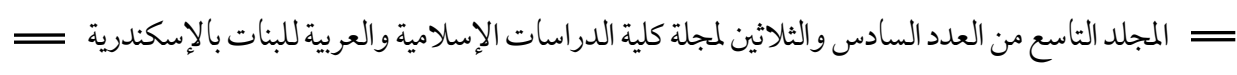
جمع القرآن ورد الشبهات حوله

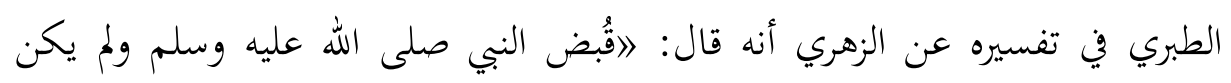

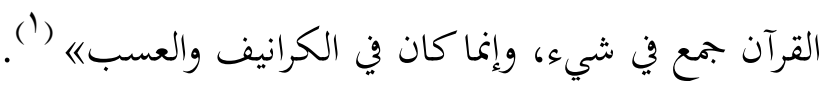

وقال ابن عبد البر: (وكان القرآن بحموعا في عهد النبي صلى الله عليه وسلم ولكنه

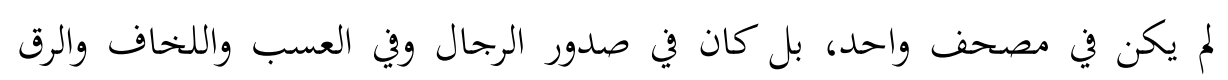
وأكتاف الإبل وما إلى ذلك) (r)

وقال ابن حجر: (إن القرآن كان كله قد كتب في عهد النبي صلى الله عليه وسلم

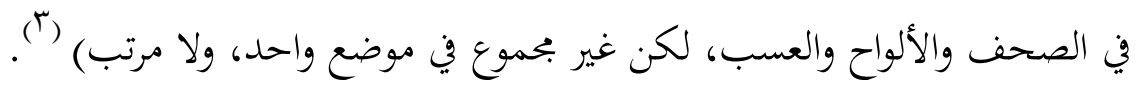
وقال السيوطي: (وإنما لم يجمع في مصحف منظم في حياة رسول الله صلى الله

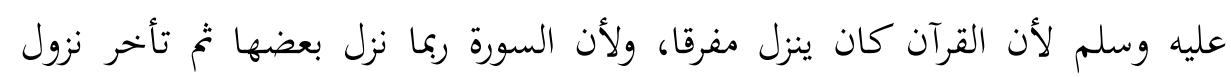
تتمتها، فكان القرآن يكتب على القطع حتى إذا توفي رسول الله صلى الله عليه وسلم

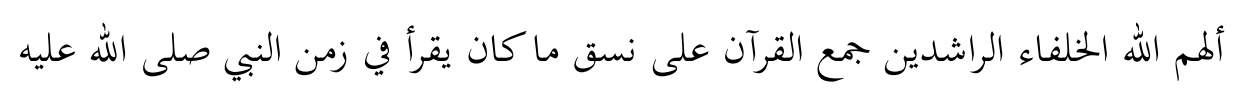

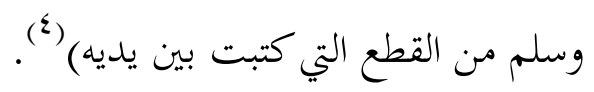

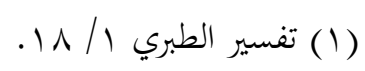

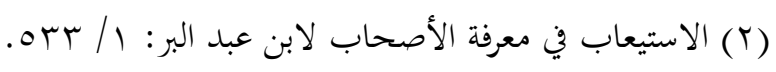

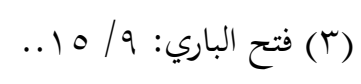

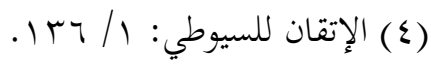

v. 


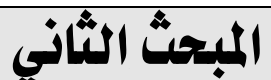

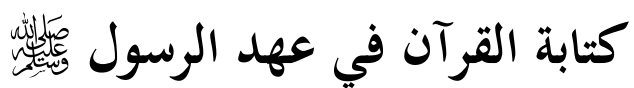

\section{أولًا: كيفية تلقي الرسول صلى الله عليه وسلم القرآن.}

كان رسول الله صلى الله عليه وسلم مولعا بالوحي، يترقب نزوله عليه بشوق، لهنيه

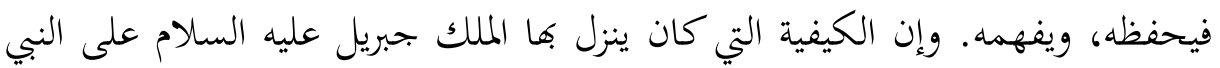

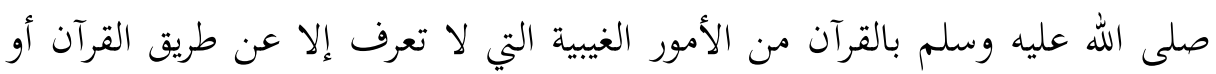

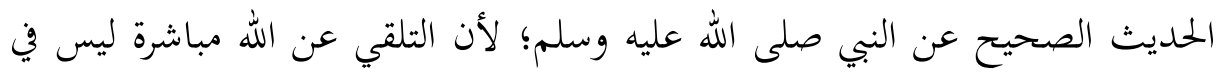

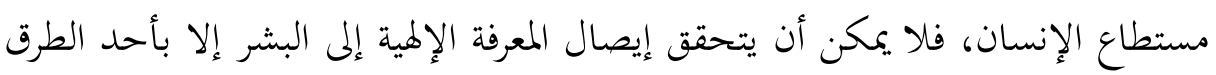

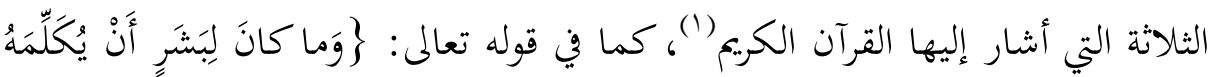

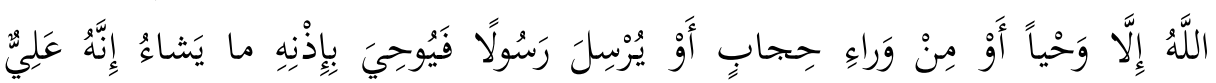
(1)

وقد بيّن النبي صلى الله عليه وسلم الكيفية التي يلقي بها الملك الوحي إليه، وشهد

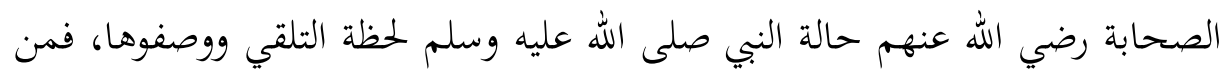

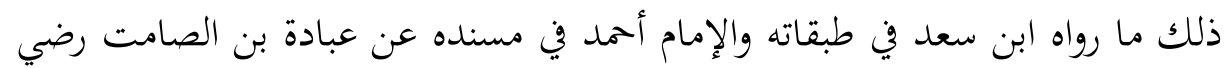

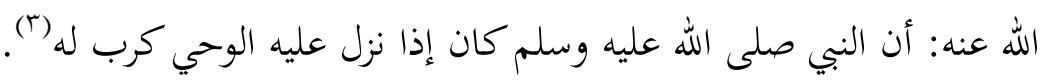

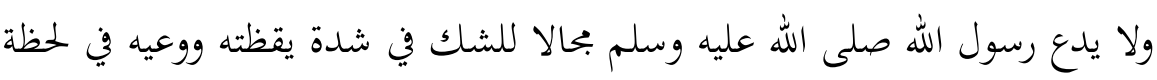

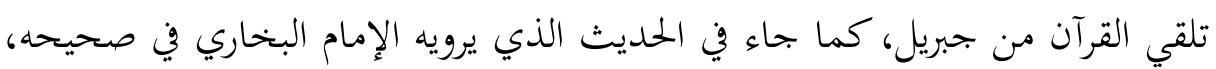

(1) الإتقان في علوم القرآن: 1/ 19 ، محاضرات في علوم القرآن، د. غانم قدوري: ص • r.

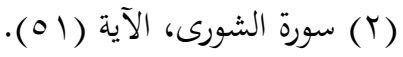

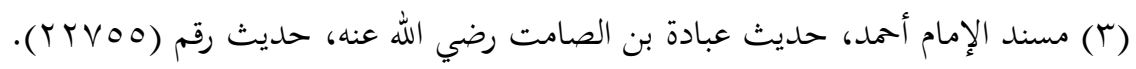


عن عائشة أم المؤمنين رضي الله عنها: أن الحارث بن هشام رضي الله عنه سأل رسول

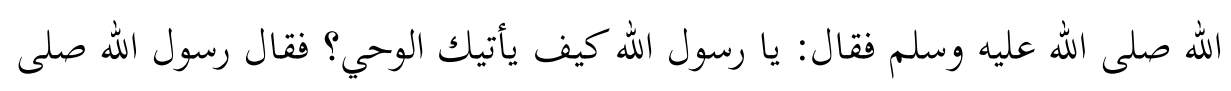

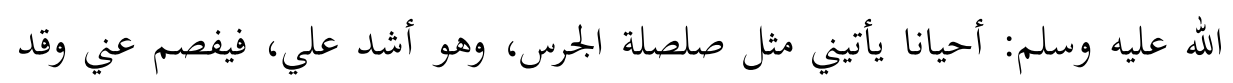

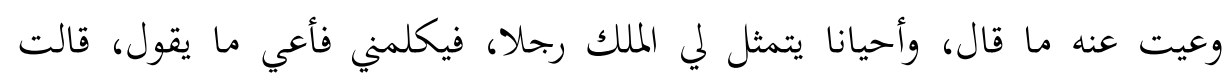

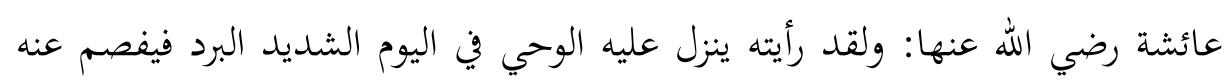

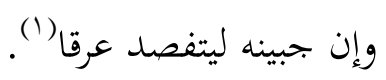

فكانت همته عليه الصلاة والسلام بادئ ذي بلدء بعد انقطاع الوحي منصرفة إلى أن

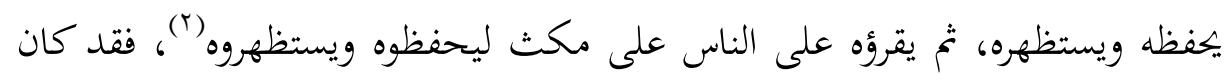

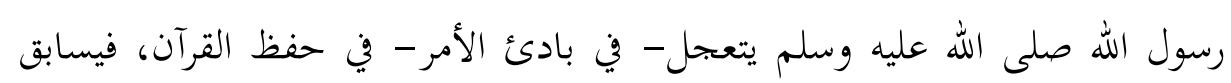

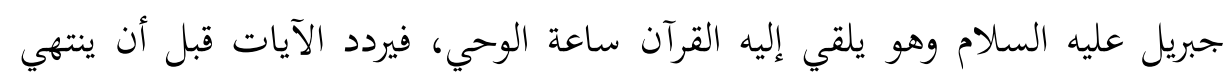

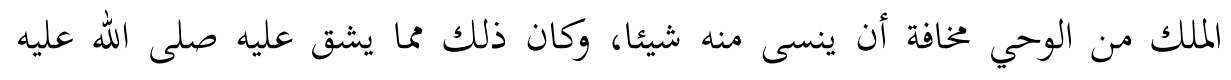

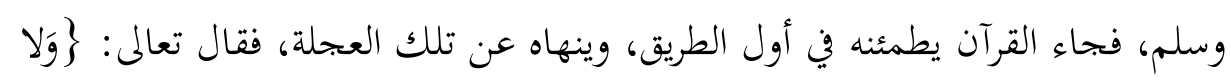

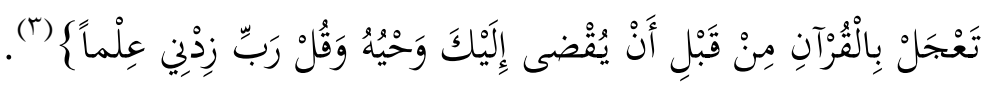
وجاءت آيات أخرى تؤكد أن حفظ القرآن مكفول للنبي صلى الله عليه وسلم، قال

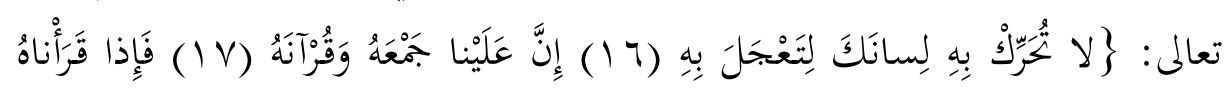

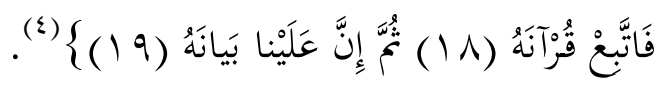

\footnotetext{
(1) صحيح البخاري، كتاب بدء الوحي، كيف كان بدء الوحي إلى الرسول صلى الله عليه وسلم،

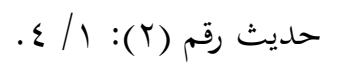

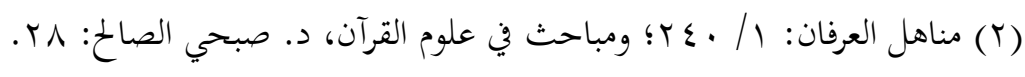

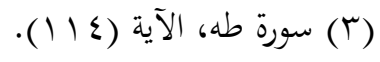

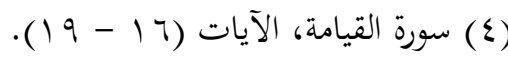


وجاء في الحديث الصحيح الذي يرويه الإمام البخاري عن ابن عباس رضي الله

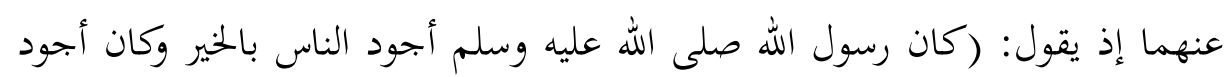
ما يكون في رمضان حين يلقاه جبريل، وكان يلقاه في كل ليلة من رمضان فيدارسه القرآن)('). قال بحاهد: (كان رسول الله صلى الله عليه وسلم يتذاكر القرآن في نفسه

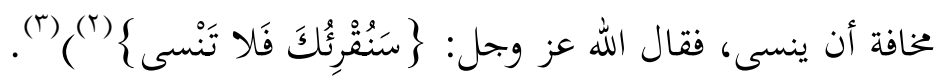
فكان رسول الله صلّى الله عليه وسلّم يقرأ القرآن في جميع أحواله؛ عن عبد الله بن مغفل رضي الله عنهم أنه قال: (رأيت رسول الله صلى الله عليه وسلم يوم فتح مكة وهو يقرأ على راحلته سورة الفتح) (ع).

وأحيانًا كان يأمر بعض الصحابة أن يقرأ عليه القرآن، كما جاء في الحديث عن عبد الله بن مسعود رضي الله عنهم أنه قال: (قال لي النبي صلى الله عليه وسلم: اقرأ

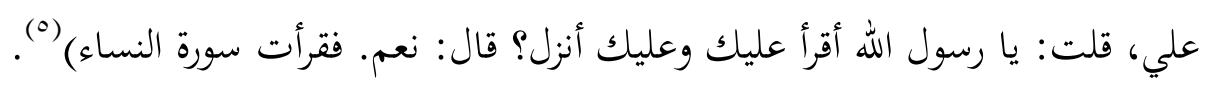
ثانيًا: كيفية تلقي الصحابة رضي الله عنهم القرآن وحفظه. شهد الصحابة رضي الله عنهم رسول الله صلى الله عليه وسلم وهو يوحى إليه، وحدثهم صلى الله عليه وسلم عن بدء الوحي وأحواله، فاستبانت من خلال ذلك كله

(1) صحيح البخاري، كتاب الصوم، باب أجود ما كان النبي صلى الله عليه وسلم يكون في

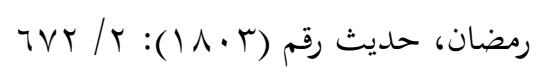

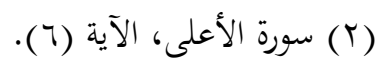$$
\text { VOr VOr) }
$$

(ع) صحيح مسلم، كتاب فضائل القرآن وما يتعلق به، باب ذكر قراءة النبي صلى الله عليه وسلم

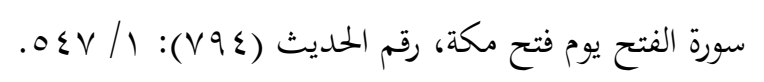

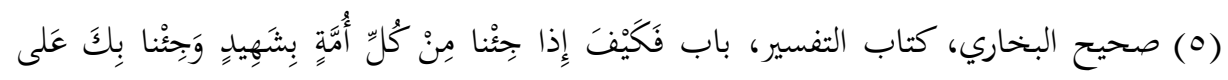

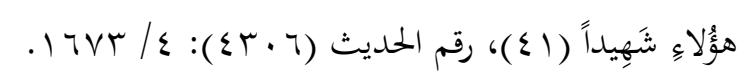


خصائص الوحي، واستقر في أفئدهم علم اليقين بأن هذا هو وحي الله العظيم إلى نبيه الكريم سيدنا محمد صلى الله عليه وسلم.

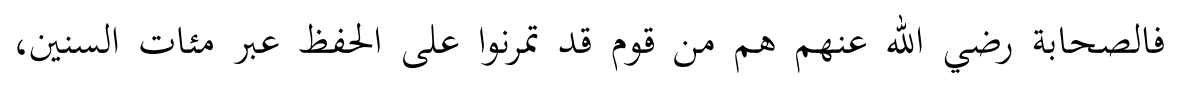
وكانوا يفتخرون بقوة حافظتهم، وجودة ملكتهم.

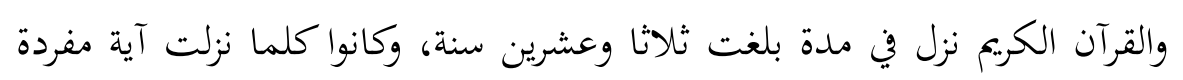

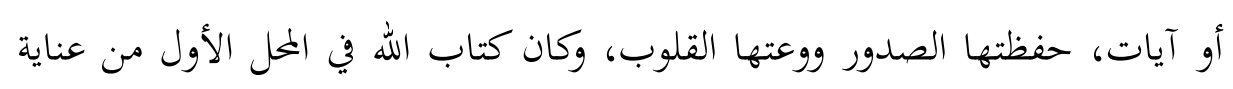

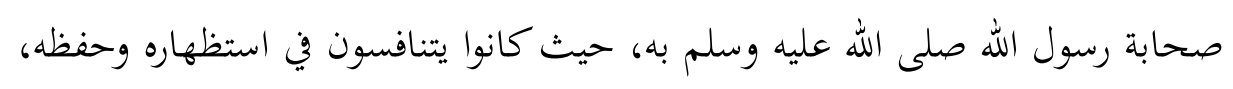

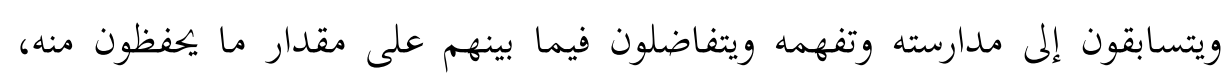

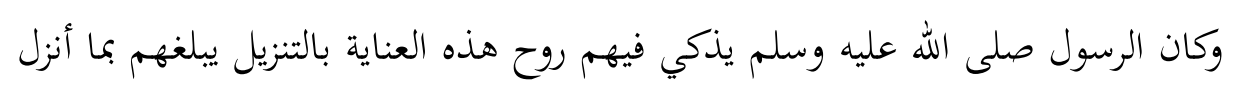

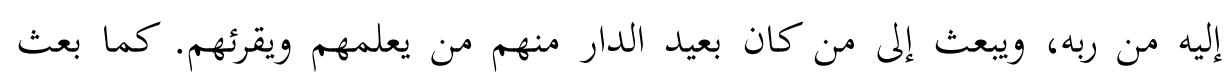

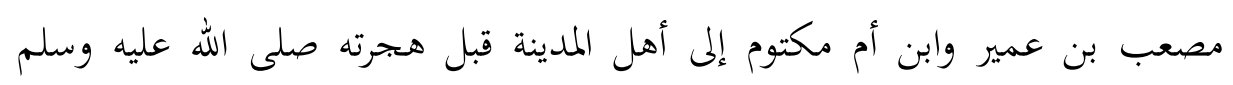

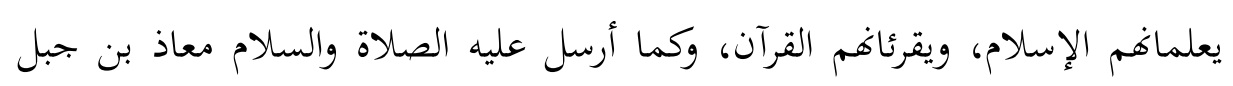
رضي الله عنه إلى مكة بعد هجرته للتحفيظ والإقراء (1). قال عبادة بن الصامت رضي الله عنه: (كان الرجل إذا هاجر دفعه النبي صلى الله

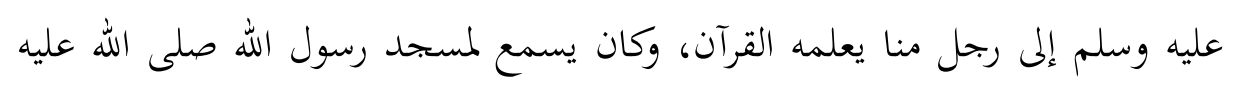

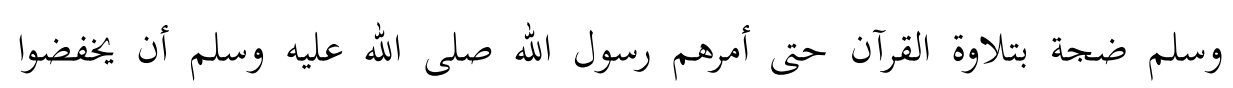
أصواقم لئلا يتغالطوا) (「) وجاء في الأثر عن عبد الله بن حبيب، أبي عبد الرحمن السلمي أنه قال: (حدثنا

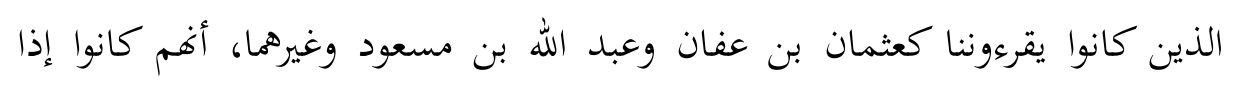

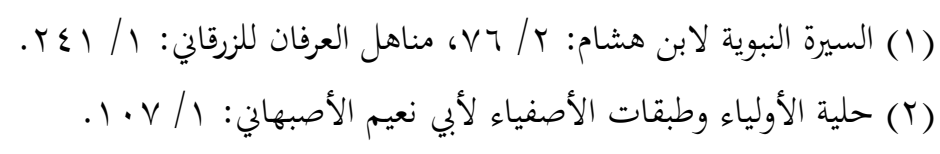




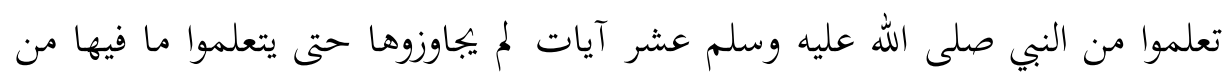

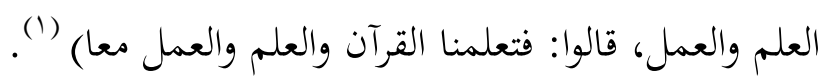

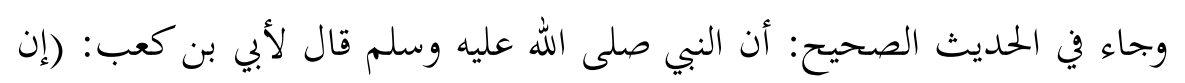

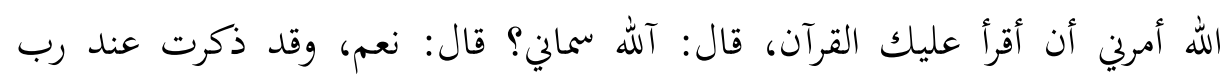

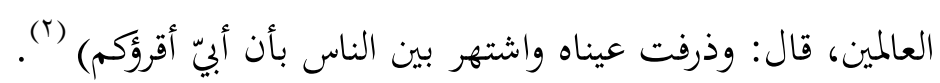

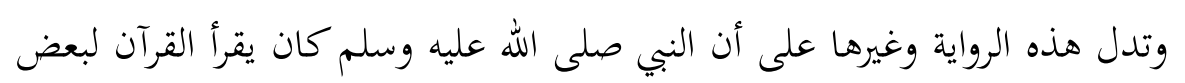

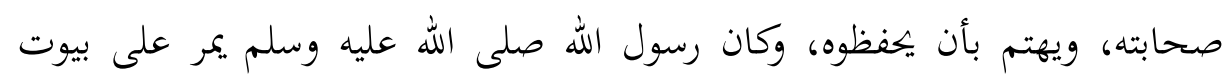

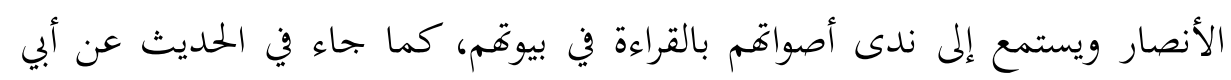

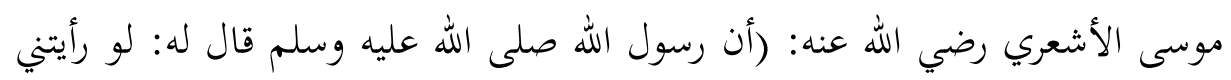

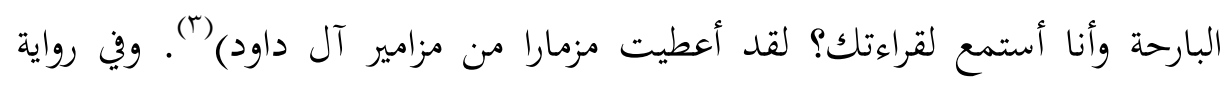

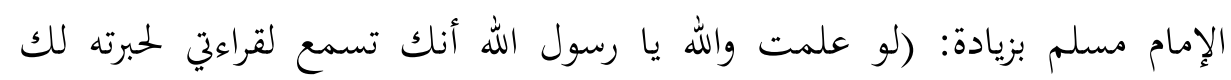

تحبيرا()

(1) مسند الإمام أحمد، حديث رجل من أصحاب النبي صلى الله عليه وسلم، حديث رقم

$:(r+r q)$

.$\leqslant 1 \cdot 10$

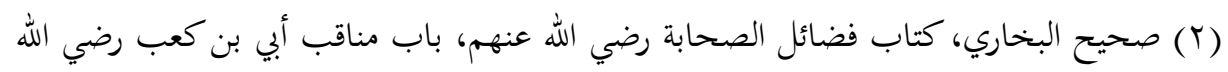

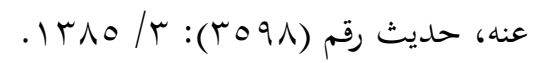

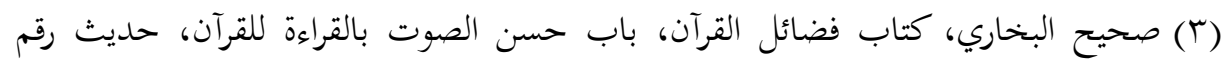

$$
.19 r 0 / \varepsilon:(\varepsilon \vee 71)
$$

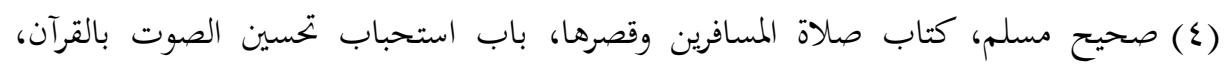

$$
\text { حديث رقم (rqT) }
$$


وبعد الحفظ والإتقان كان كل حافظ ينشر ما حفظه ويعلمه للأولاد والصبيان،

والذين لم يشهدوا النزول ساعة الوحي، وكان الحفظة والقراء يعرضون على النبي صلى لهلى الله عليه وسلم ما كانوا يجفظون من القرآن (1).

ومن هنا كان حفاظ القرآن في حياة الرسول صلى الله عليه وسلم جما غفيرا من

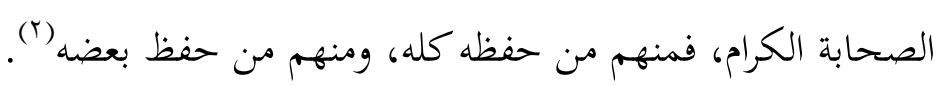

ولعل من أهم العوامل التي ساعدت الصحابة رضي الله عنهم على حفظ كتاب الله

وتعلمه هو: وجود الرسول صلى الله عليه وسلم بين ظهرانيهم، يحفظهم من الكتاب

والسنة ما لم يجفظوه ويعلمهم ما جهلوه، ويجيبهم إذا سألوه (r).

وكذلك ينبغي عدم التقليل من أهمية المشافهة والحفظ، لأن الصحابة رضي الله

عنهم حفظوا الحكم والأمثال والقصص والأشعار في الجاهلية فكيف لا تتوافر همهم على حفظ القرآن في الإسلام، وهو أساس علاقتهم ودستور حياهم (ع).

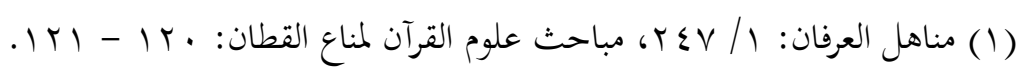

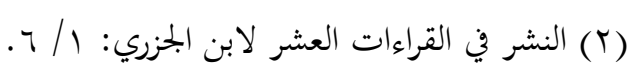

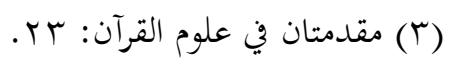

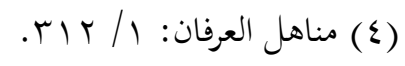




\section{المبحثُ الثُالث}

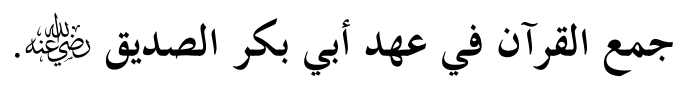

أولاًا: فكرة جمع القرآن في عهد أبي بكر الصديق رضي الله عنه وسببها.

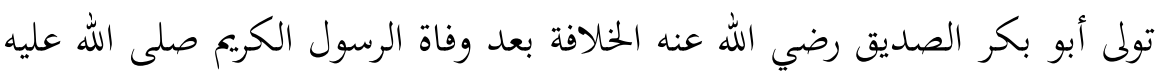

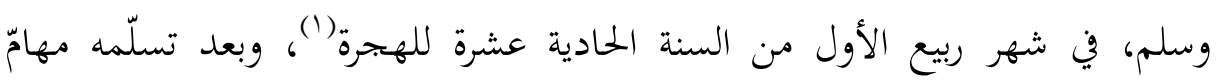

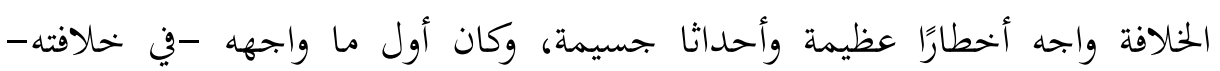

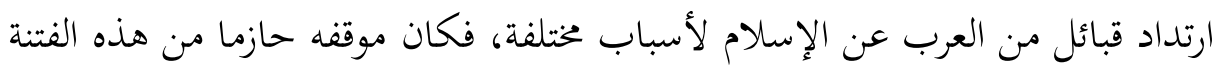

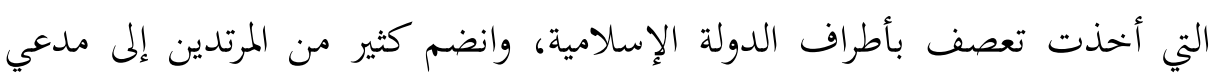

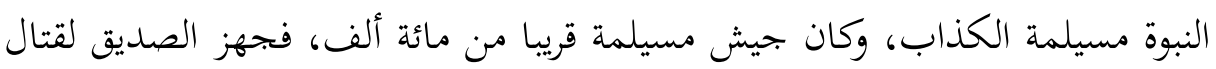

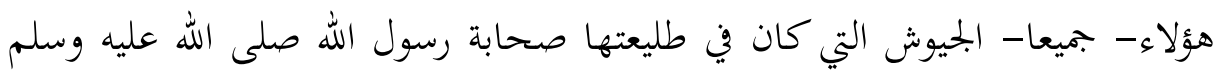

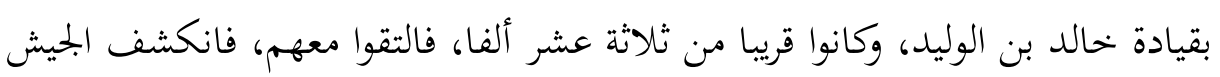

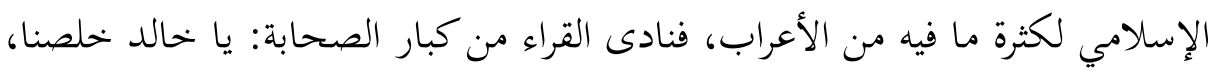

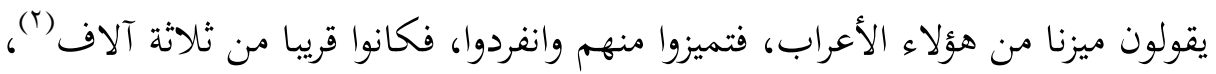

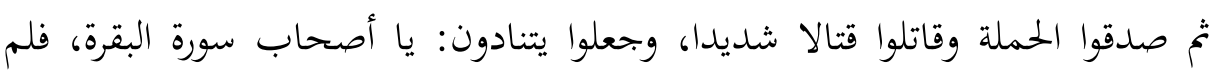

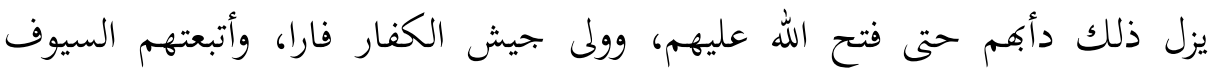

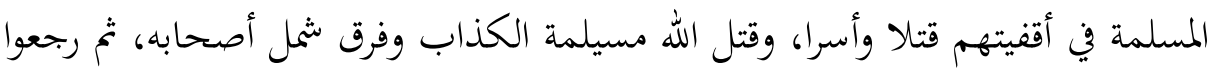

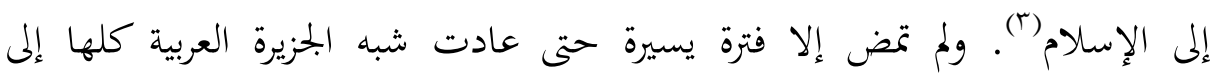

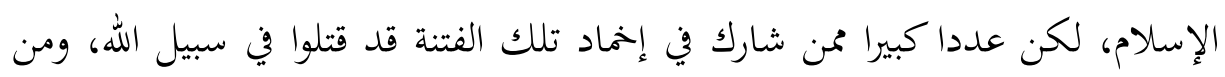

$$
\begin{aligned}
& \text { (1) تاريخ خليفة، خليفة بن الخياط: / / V9. }
\end{aligned}
$$

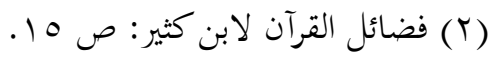

$$
\begin{aligned}
& \text { (T) فضائل القرآن لابن كثير: ص آ } 10 .
\end{aligned}
$$


بينهم عدد من حفاظ القرآن، وتشير الروايات إلى أن معركة اليمامة التي أذل الله فيها ولها

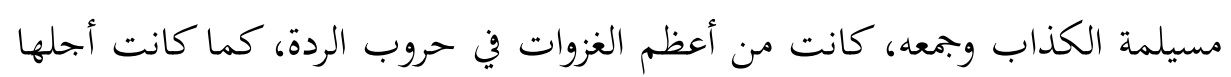

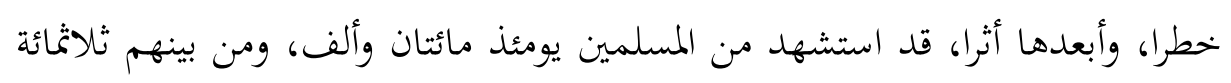

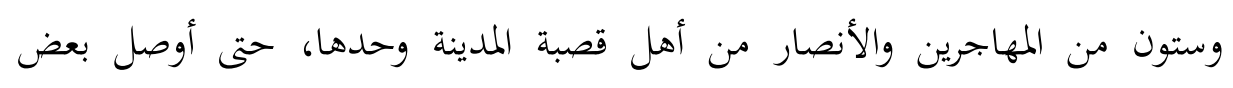

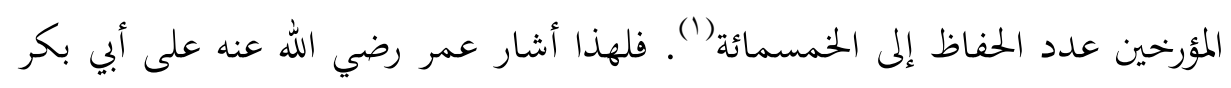

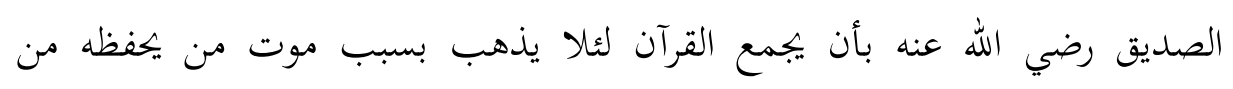
الصحابة بعد ذلك في مواطن القتال (r).

\section{ثانيًا: لجنة جمع القرآن في عهد أبي بكر الصديق القيق رضي الله عنه.}

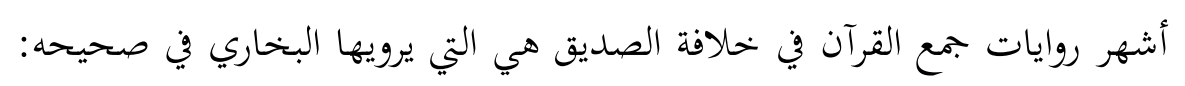

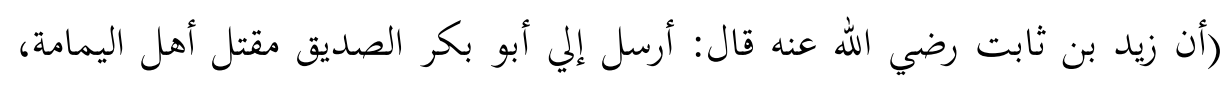

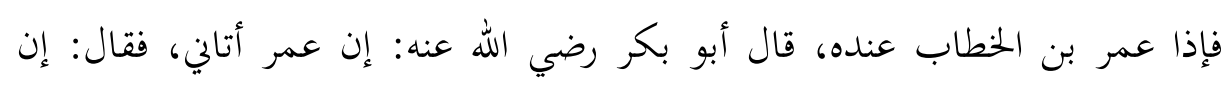

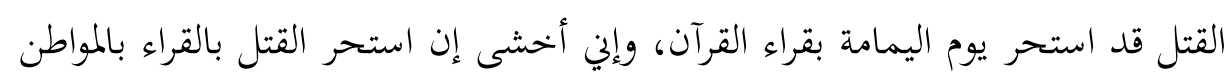

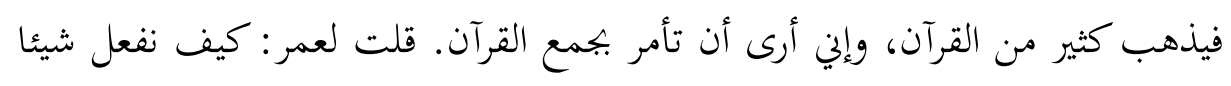

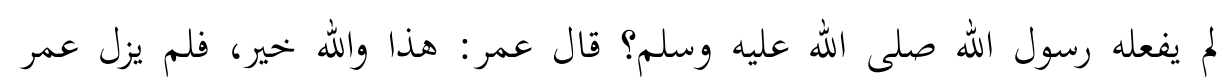

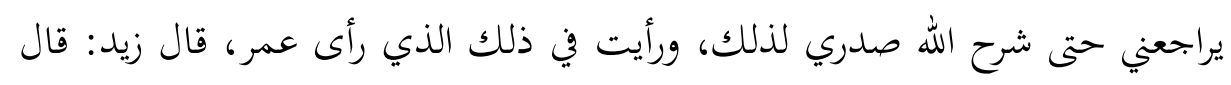

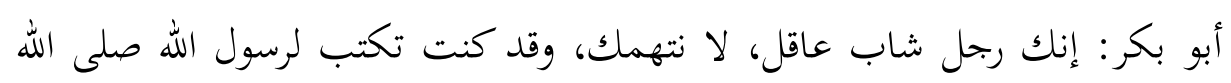

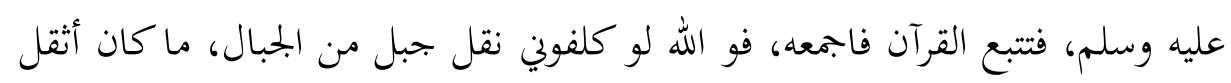

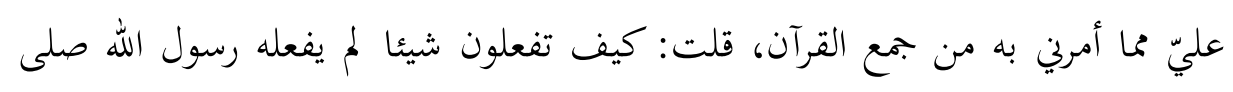

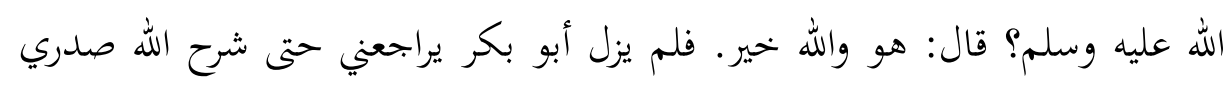

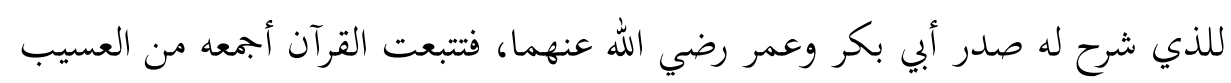

$$
\begin{aligned}
& \text { (1) النشر في القراءات العشر: 1/ V. V. } \\
& \text { (T) فضائل القرآن لابن كثير: ص (T) } 10 .
\end{aligned}
$$




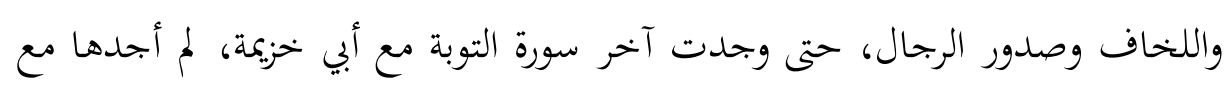

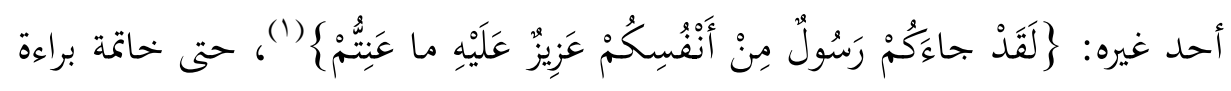

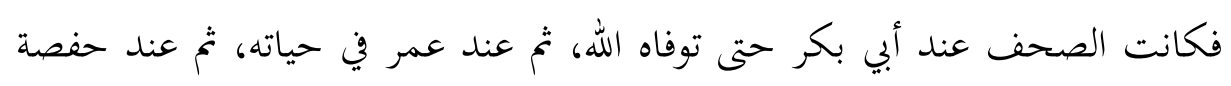

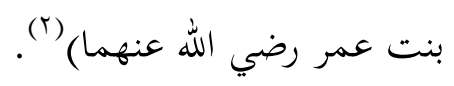

تشير تلك الرواية إلى الصفات والمؤهلات التي جعلت أبا بكر الصديق رضي الله

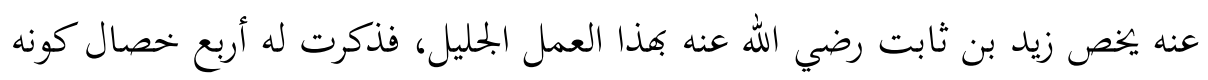

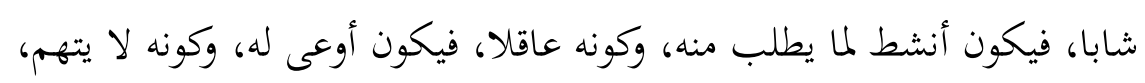
فتركن النفس إليه، وكونه كان يكتب الوحي، فيكون أكثر ممارسة له (بان.

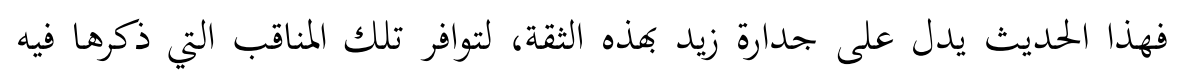

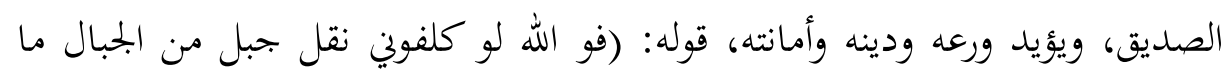
كان أثقل علي مما أمرين به من جمع القرآن) (عُ وأن.

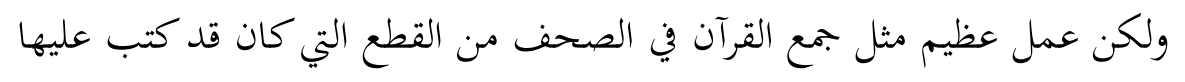

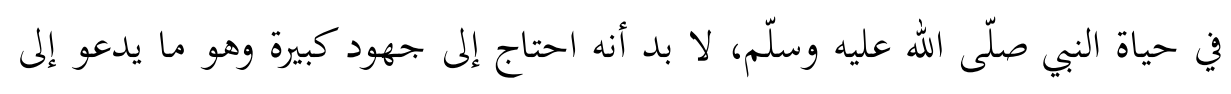

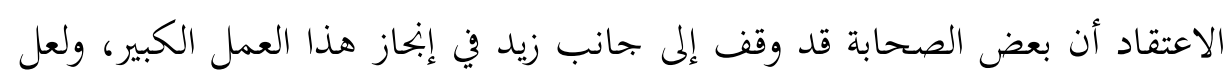

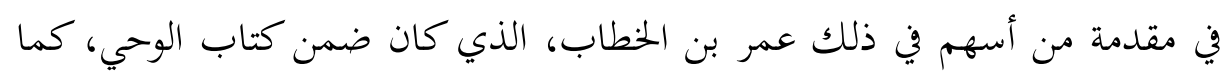

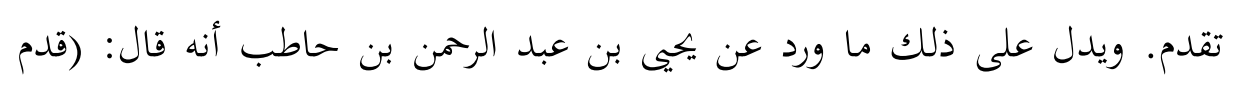

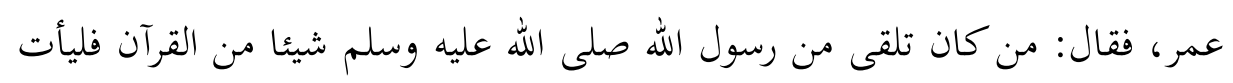




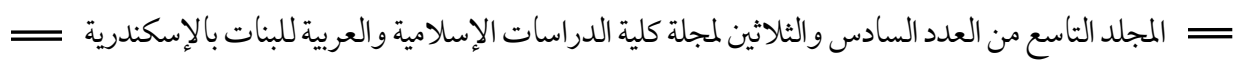
جمع القرآن ورد الشبهات حوله

به، وكانوا يكتبون ذلك في الصحف والألواح والعسب، وكان لا يقبل من أحد شيئا

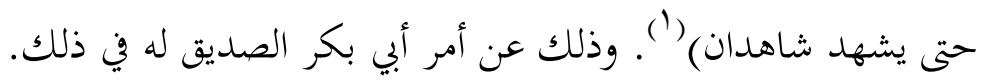

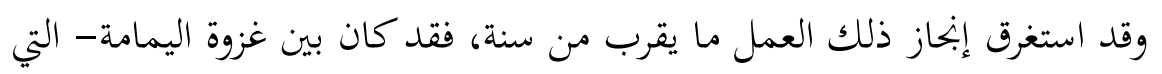

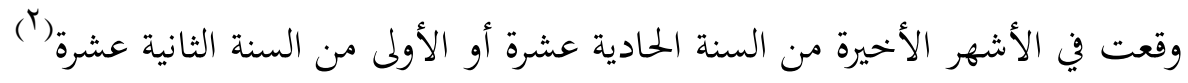

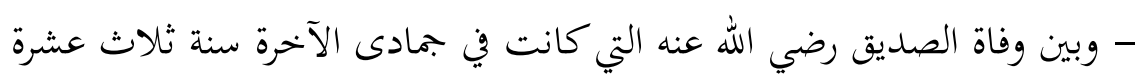

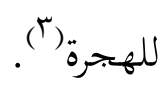

ولا شك في أنه اكتمل العمل قبل وفاة الصديق إذ أن الروايات تشير إلى أن أن أنداء الصحف أودعت عنده بقية حياته، ثم أخذها عمر بعده. 


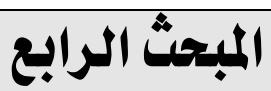

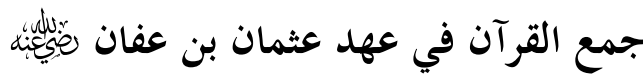

أولاً: الأسباب التي أدّت إلى فكرة توحيد المصاحف على مصحف واحد.

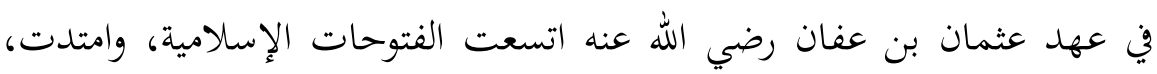

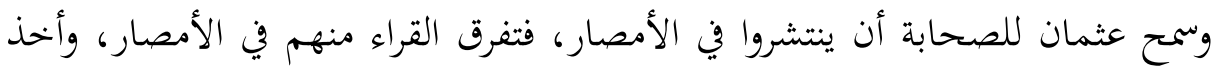
أهل كل مصر عن من وفد إليهم من القرّاء (').

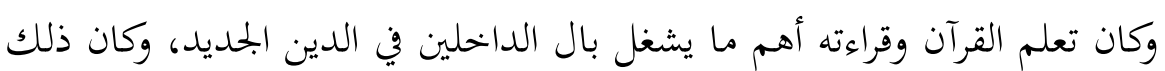

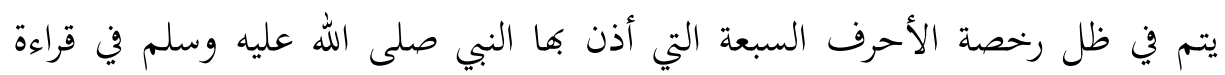

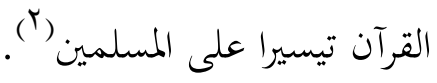

وكان أهل كل إقليم من الأقاليم يأخذون بقراءة من اشتهر بينهم من الصحابة، فكان بينهم اختلاف في حروف الأداء ووجوه القراءة").

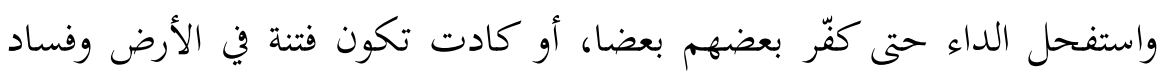

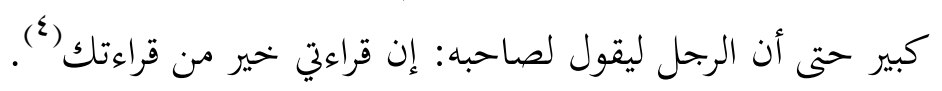

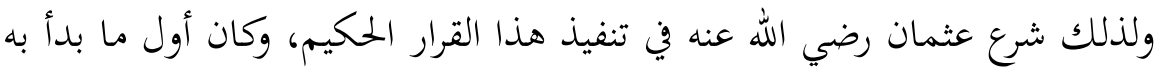
لتحقيق ذلك، أن خطب الناس في المدينة، وفيهم كثير من الصحابة، يستشيرهم

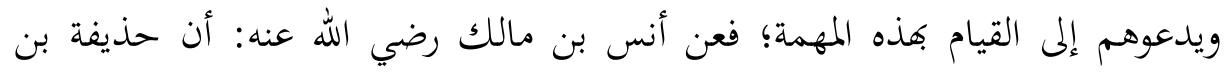

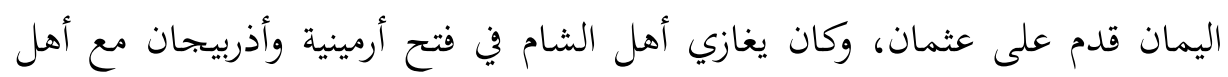

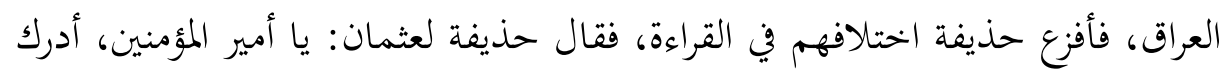

$$
\begin{aligned}
& \text { (1) رسم المصحف، د. غانم قدوري: صV •1. }
\end{aligned}
$$

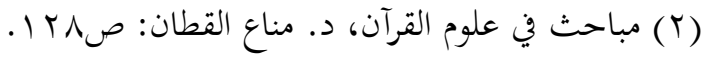

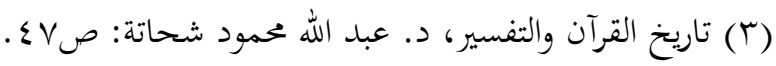

$$
\begin{aligned}
& \text { (ع) المرشد الوجيز لأبي شامة المقدسي: صعانه }
\end{aligned}
$$




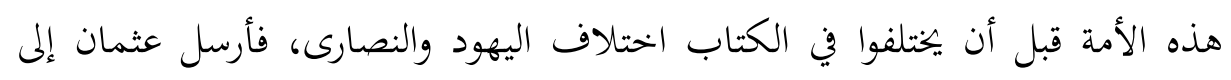

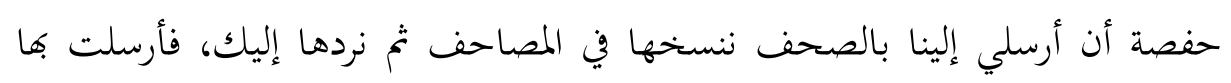

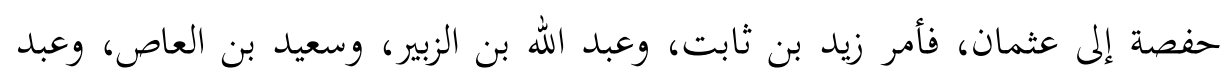

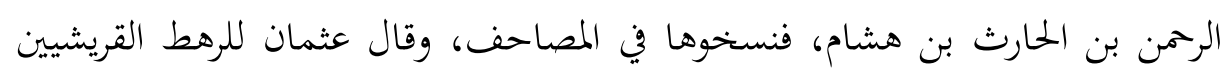

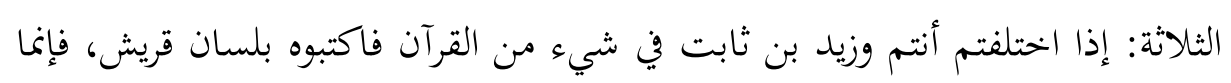

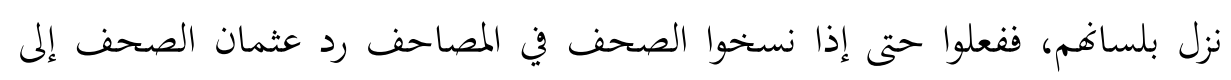

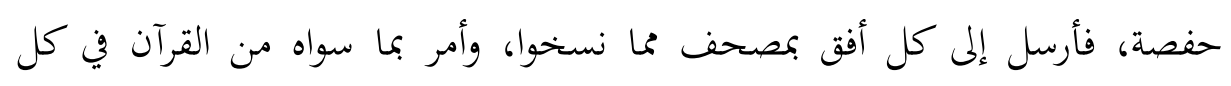

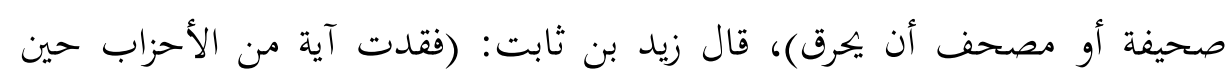

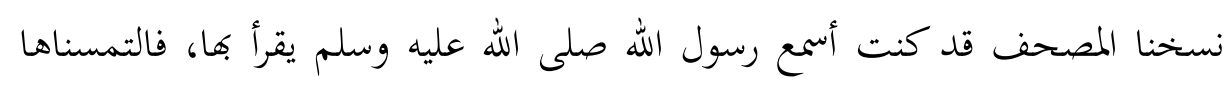

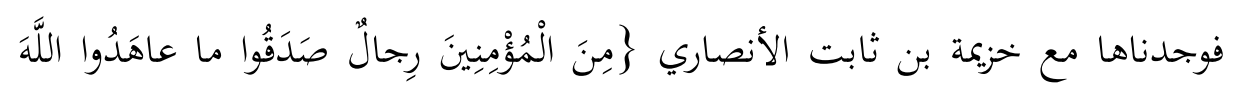

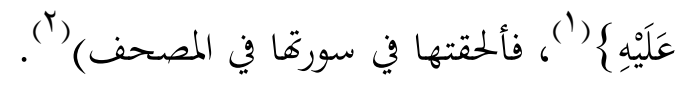

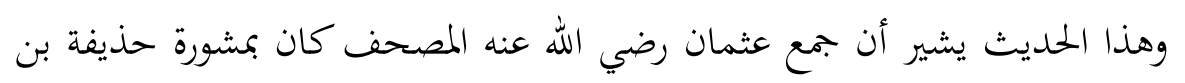

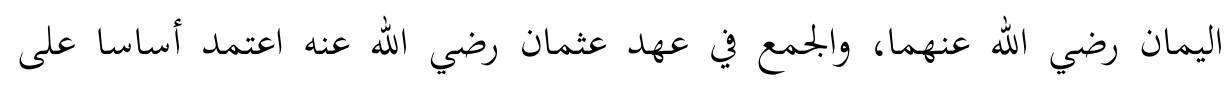

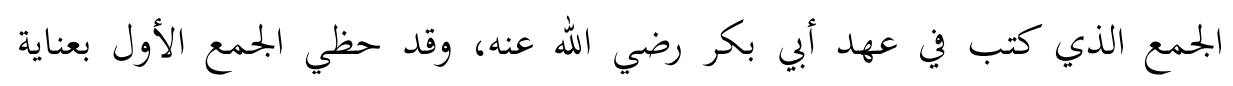
الصحابة وموافتنهم.

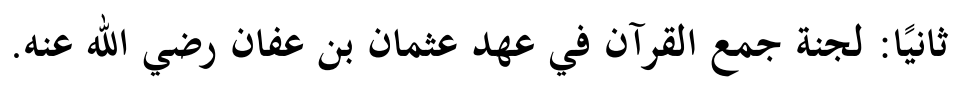

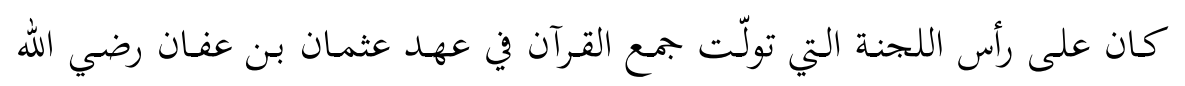

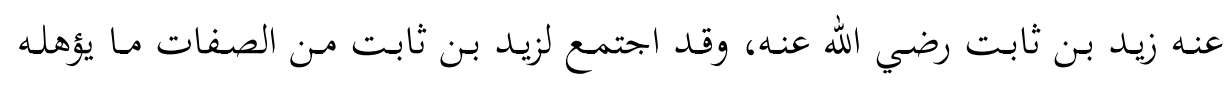

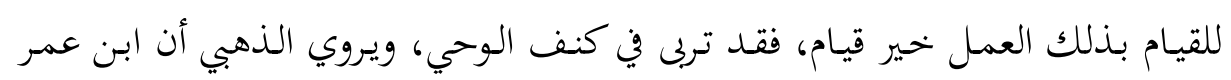

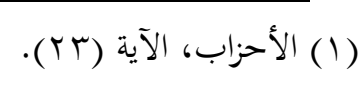

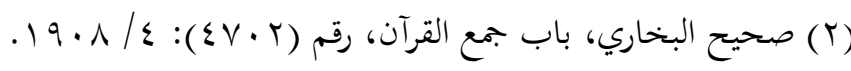


قال يوم مات زيد بن ثابت: (يرحمه الله، فقد كان عالم الناس في خحلافة عمر وحبرها،

فرقهم عمر في البلدان وهاهم أن يفتوا برأيهم، وحبس زيد بالمدينة يفتي أهلها) (').

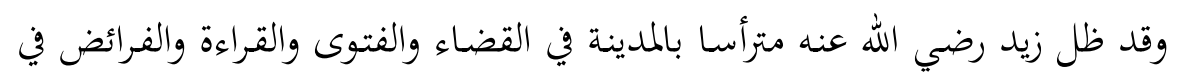
عهد عمر وعثمان وعلي رضي الله عنه أجمعين، حتى توفي سنة خمس وأربعين (r). أما الثلاثة الذين تشير الرواية التي في صحيح البخاري إلى اشتراكهم مع زيد فهم:

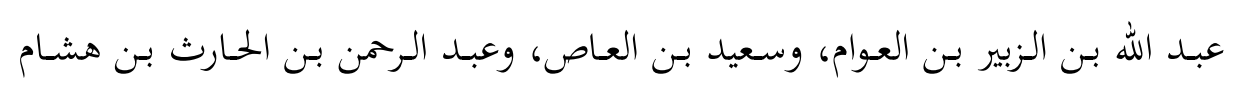

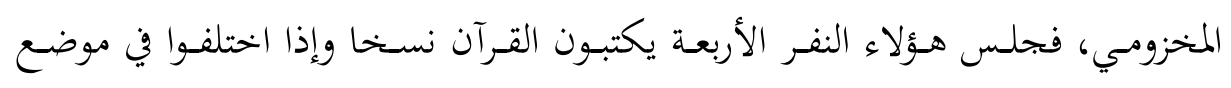
الكتابة على أي لغة، رجعوا إلى عثمان، كمـا اختلفوا في التـابوت، أيكتبونه بالتـاء أو

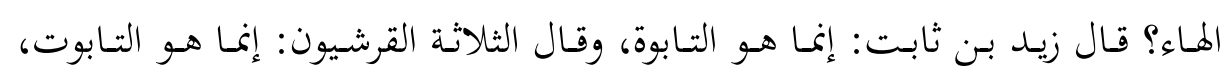

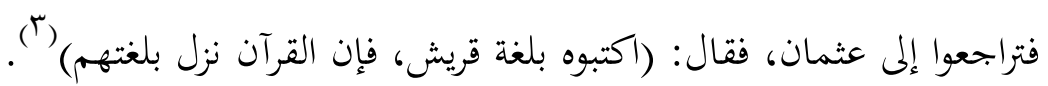
ثالثًا: عدد المصاحف التي تم نسخها في عهد عثمان بن عفان رضي الله عنه. بعد أن أتم عثمان رضي الله عنه نسخخ المصحف، أرسل إلى كل أفق مـن الأقطار

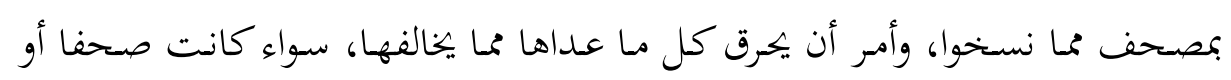
مصاحف؛ وذلك ليقطع عرق النزاع من هذه الأمة(ء). والفرق بين الصحف والمصاحف: (أن الصحف الأوراق البحردة التي جمع فيها القرآن

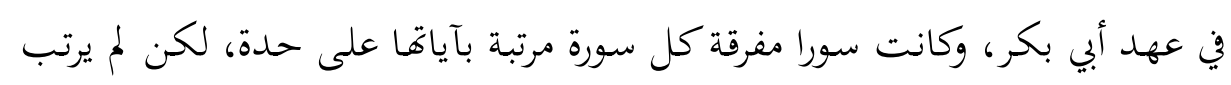
بعضها إثر بعض، فلما نسخت ورتب بعضها إثر بعض صارت مصحفا) (0).

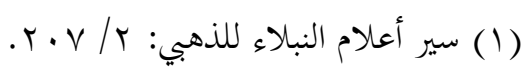

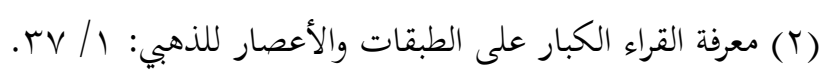

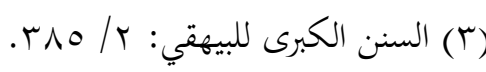

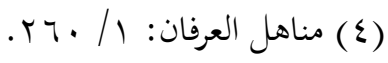

$$
\begin{aligned}
& \text { (0) الكلمات الحسان في الحروف السبعة وجمع القرآن للشيخ محمد نجيب المطيعي: ص . ه. }
\end{aligned}
$$




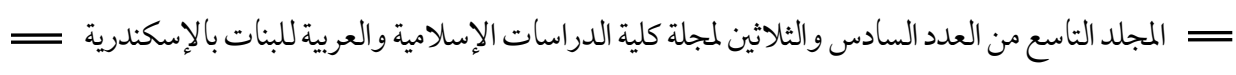

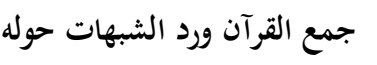

وأكثر العلماء على أن عثمان بن عفان رضي الله عنه لماكتب المصحف جعله على أربع نسخ، وبعث إلى كل ناحية من النواحي بواحدة منهن. فوجه إلى الكوفة إحداهن،

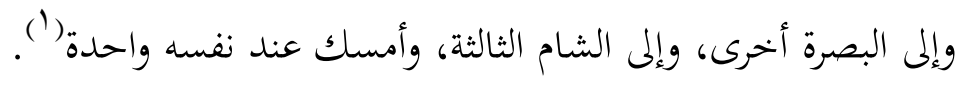
ورضي الله عن عثمان، فقد أرضى بذلك العمل الجليل ربه، وحافظ على القرآن،

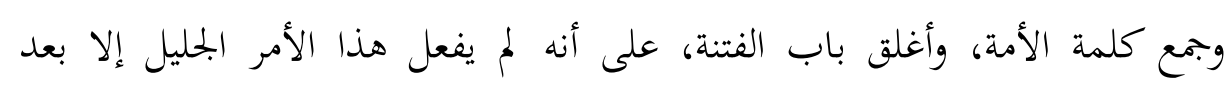
استشارة الصحابة واكتساب موافقتهم، بل وظفر بمعاونتهم وتأييدهم وشكرهم (r).

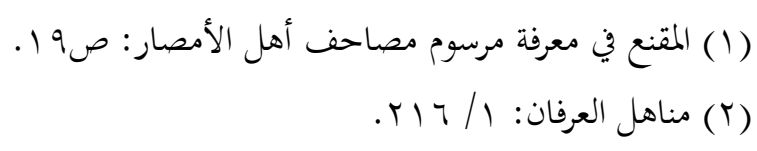




\section{المبحث الخامس}

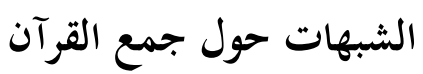

كان القرآن الكريم ولا يزال هدفا لأعداء الإسلام، يسددون إليه سهام المطاعن،

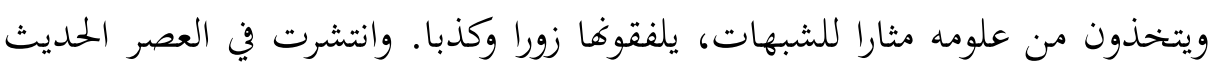

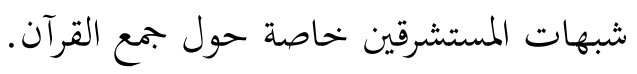

والمقصود بالاستشراق هو: دراسة غير الشرقيين لحضارات الشرق وأديانه ولغاته

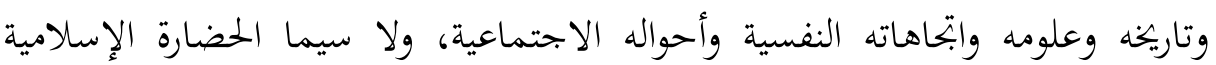
وأحوال المسلمين في مختلف العصور ('). وقيل: الاستشراق هو: علم يدرس لغات الشرق وتراثهم وحضارةم وبحتمعاقم

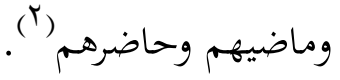

والاستشراق كان وما يزال جزءا لا يتجزأ من قضية الصراع الحضاري بين العالم

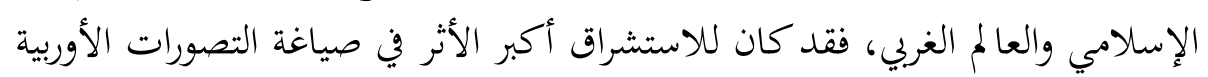
عن الإسلام، وفي تشكيل مواقف الغرب إزاء الإسلام على مدى قرون عديدة. وسوف نورد هنا شبه هؤلاء المستشرقين، ونرد عليها إن شاء الله تعالى.

$$
\text { (1) (1) الاستشراق والتبشير، قراءة تاريخية للدكتور سيد الجليند: صـ • 1. }
$$




\section{أولًا: الشبهات حول جمع القرآن في عهد النبي صلى الله عليه وسلم}

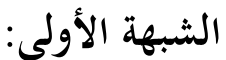

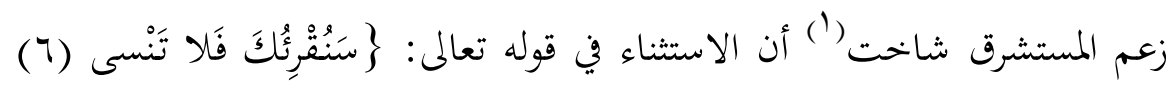

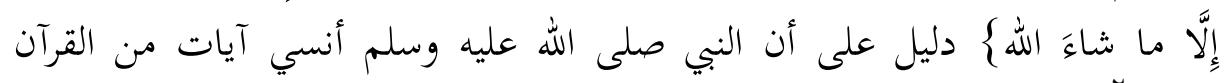

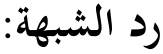

$$
\begin{aligned}
& \text { قال الإمام الباقلاني: "قوله: }\} \text { فَلا تَنْسى\{، أورد على وجه الإخبار لا على وجه لإنها } \\
& \text { الأمر، لأن النسيان لا يفعل ولا ينزل"("). } \\
& \text { الاستثناء في الآية له معنيان: - ان }
\end{aligned}
$$

الأول: أنه استثناء صوري، فلا يدل على ما زعموا، قال الزرقاني: "إن هذا

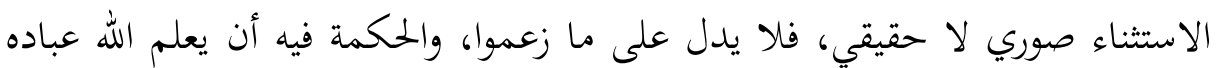

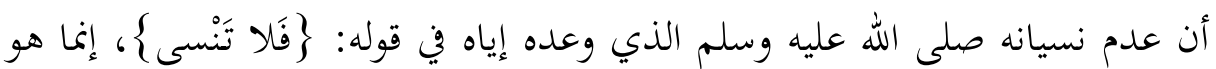
محض فضل من الله وإحسان، ولو شاء سبحانه أن ينسيه لأنساه، وفي ذلك الكان الاستثناء

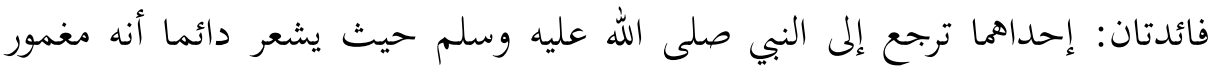

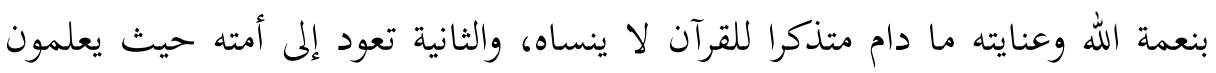

(1) هو: يوسف شاخت، مستشرق ألماني، متعصب ضد الإسلام والمسلمين، له كتب كثيرة في الفقه الإسلامي وأصوله، مات سنة 979 ام. ينظر: مناهج المستشرقين للدكتور سعدون

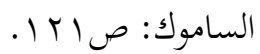

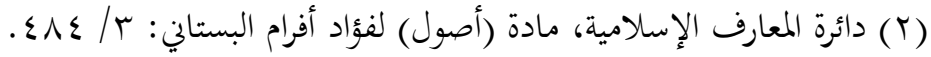

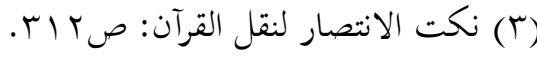




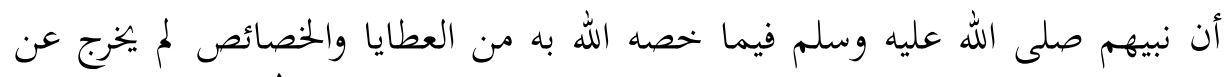

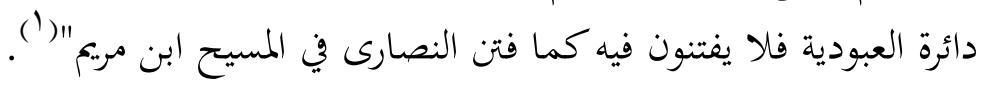

الثاني: أنه استثناء حقيقي، والمراد به نسيان منسوخ التلاوة، ويكون معنى الآية: أن

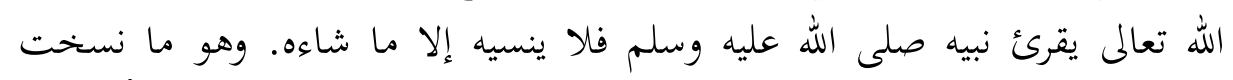

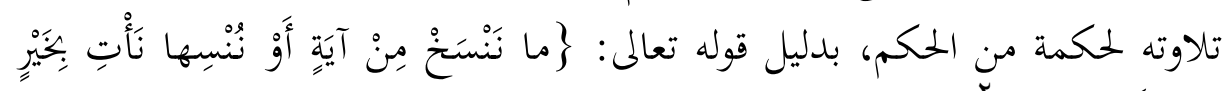

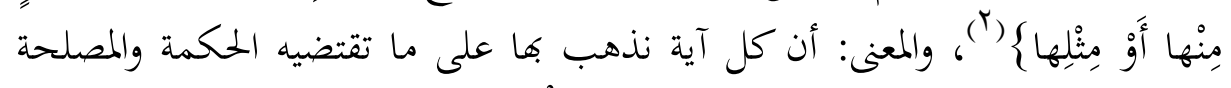

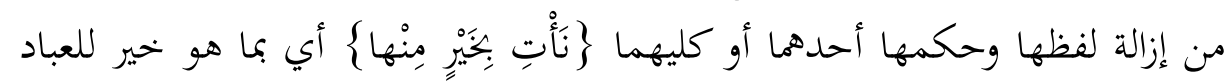

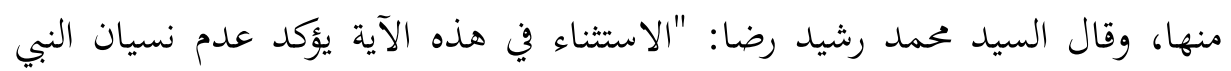

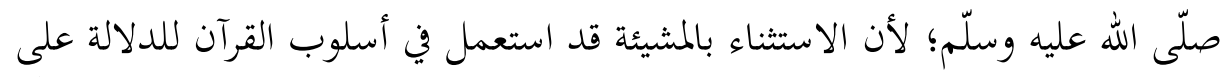

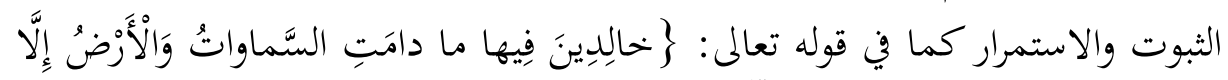

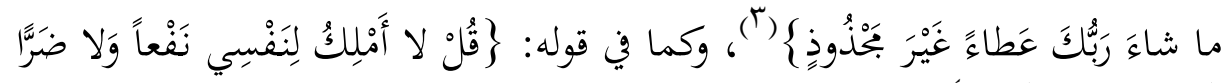

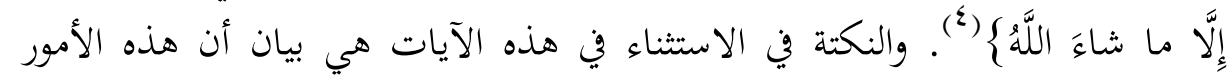

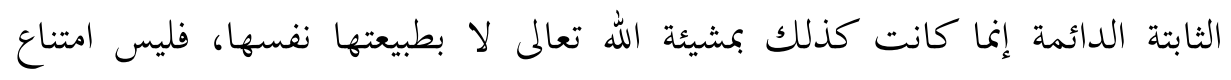

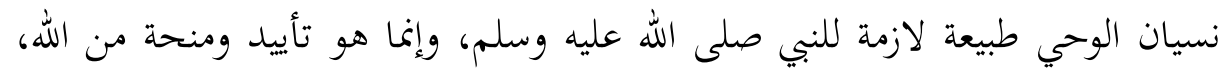
وليس خلود أهل الجنة في الجنة واجبا عقليا أو طبيعيا، وإنما هو بإرادة الله ومشيئته" (0).

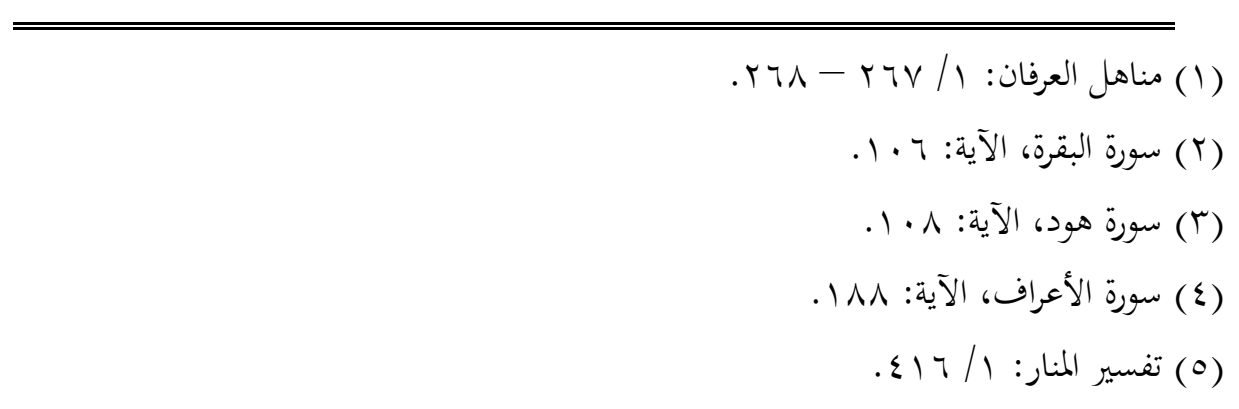




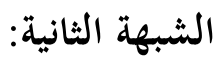

زعم بعض المستشرقين أن قول النبي صلى الله عليه وسلم قال: (رحم الله فلانا لقد

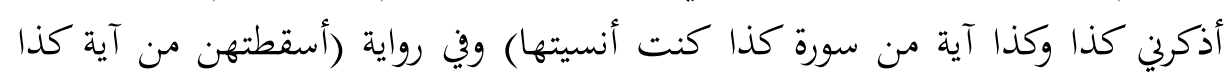

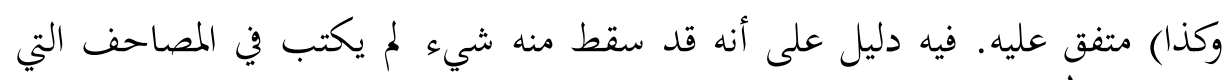

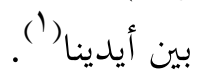

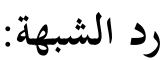

هذا النوع من النسيان لا يزعزع الثقة بالرسول صلى الله عليه وسلم، ولا يشكك في دقة جمع القرآن ونسخه، فإن الرسول صلى الله عليه وسلم كان قد حفظ هذه النه الآيات

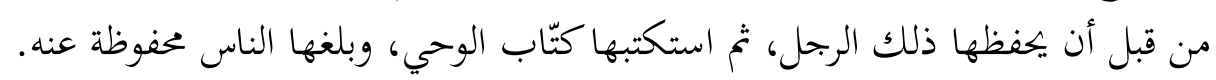
وليس في الحديث الذي احتجوا به أن هذه الآيات لم تكن بالمففوظات التي كتبها

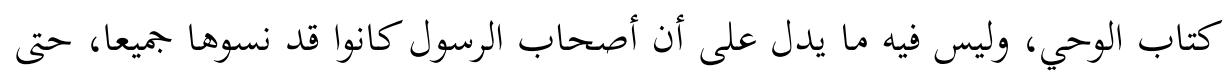

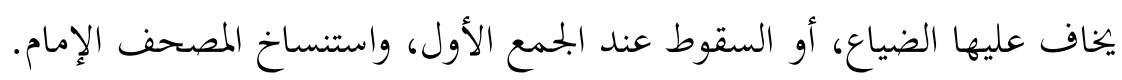
قال الإمام النووي: "قوله صلى الله عليه وسلم: (كنت أنسيتها) يدل على جواز

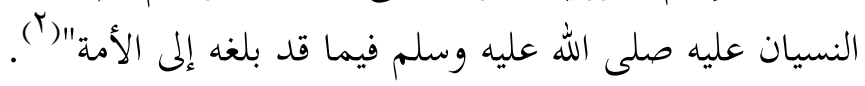

وقال ابن حجر: "جمهور المققين على جواز النسيان عليه صلى الله عليه وسلم

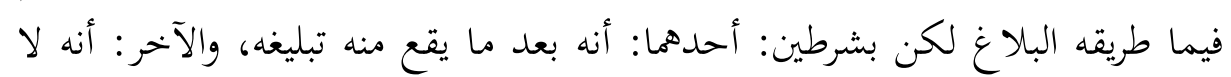
يستمر على نسيانه بل يكصل له تذكرة إما بنفسه وإما بغيره"("آ).

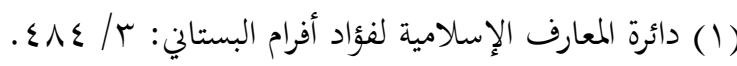

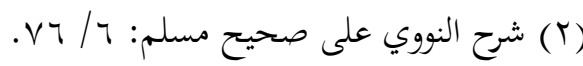

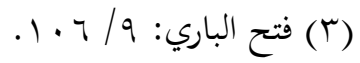




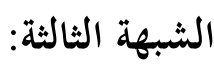

زعم المستشرق جيفري(') في مقدمته لكتاب المصاحف أن النبي صلى الله عليه

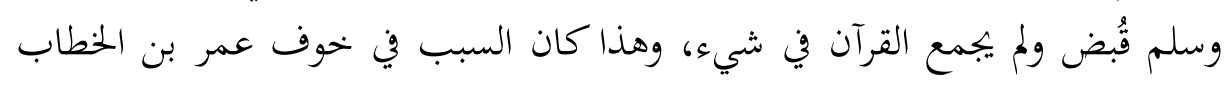

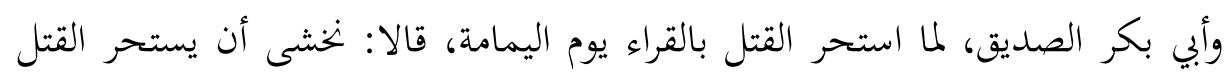

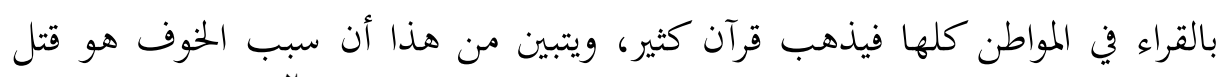

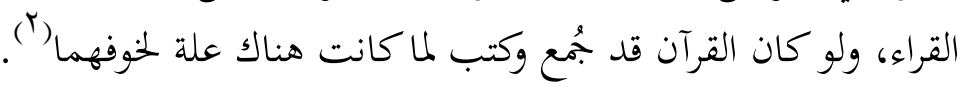

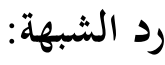

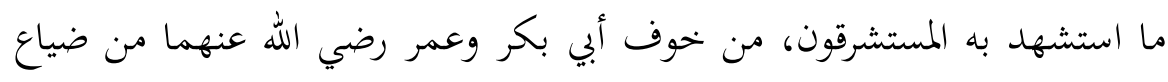

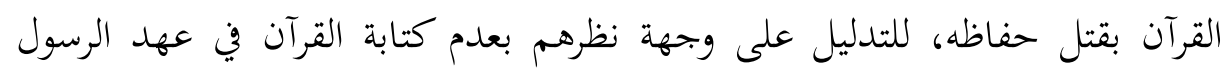

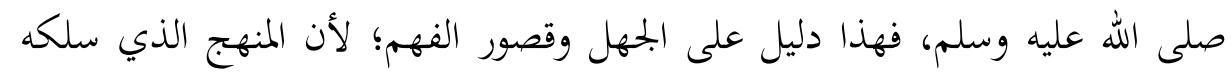

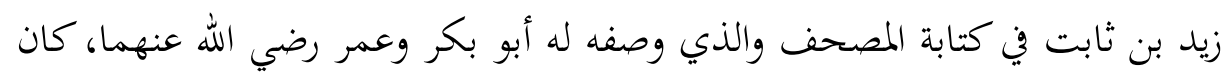

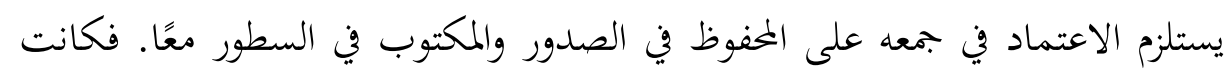

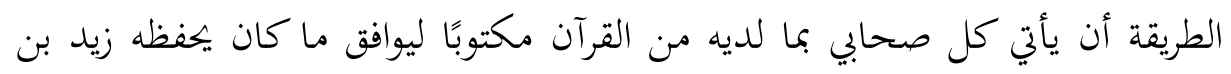

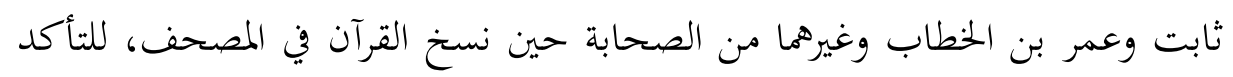

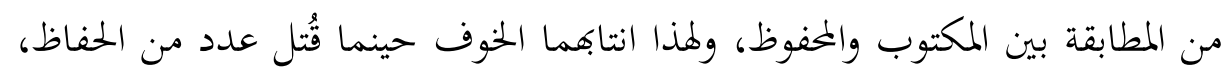

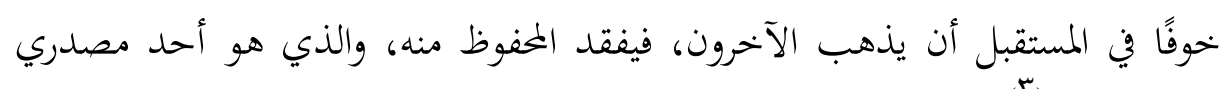
النص القرآني (").

(1) هو: آرثر جيفري، مستشرق أسترالي بروتستانتي، ولد سنة بولامام، كان كثير الطعن في القرآن

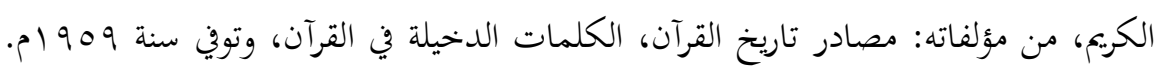

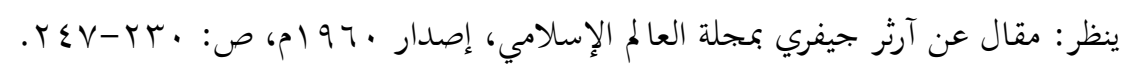

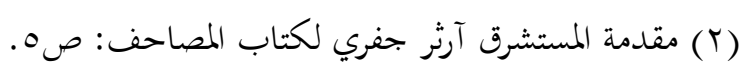

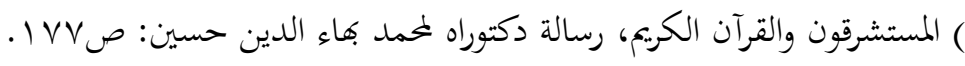




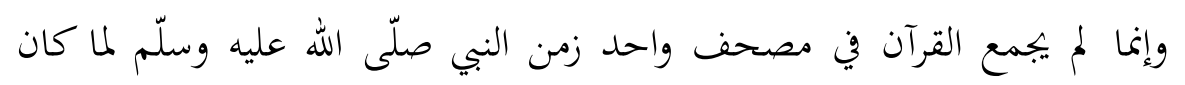

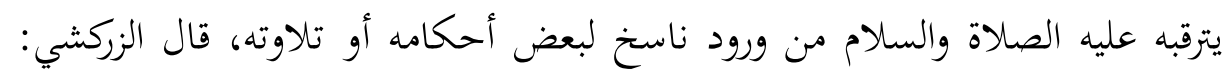

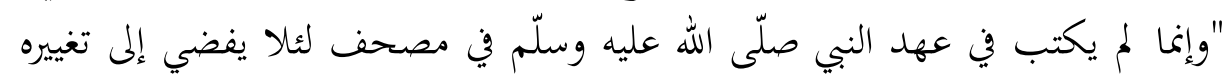

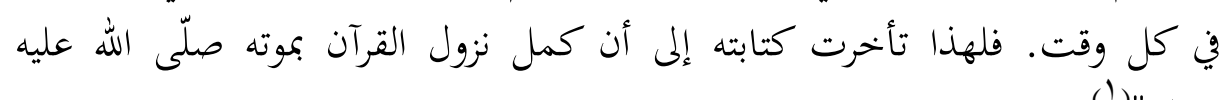

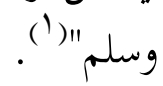

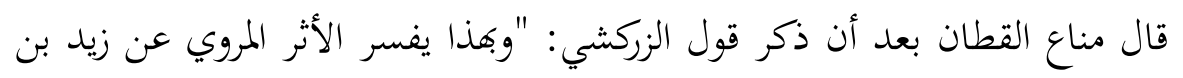

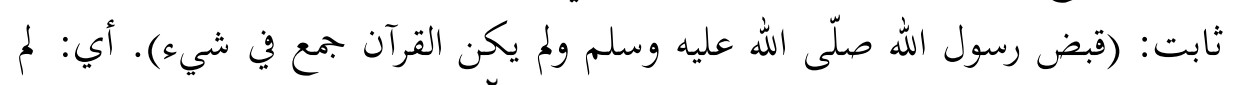

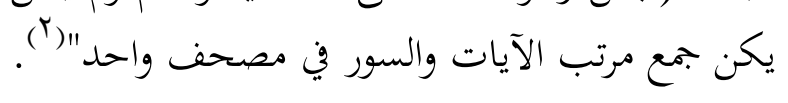

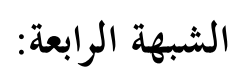

قال المستشرق ريبي بلاشير (r) في كتابه (القرآن نزوله وتدوينه): "يبدو فكرة تدوين

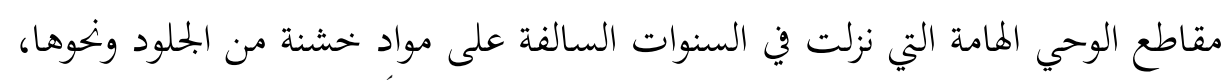

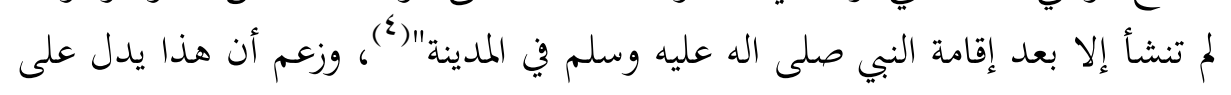

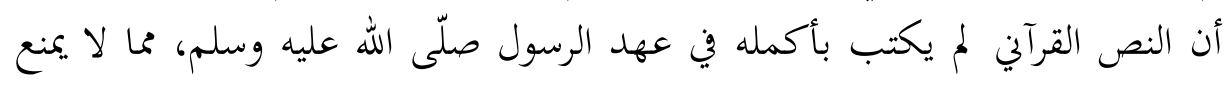

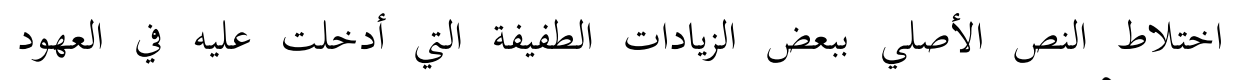
المتأخرة (0).

\footnotetext{
(1) البرهان في علوم القرآن للزركشي: / / ربات.

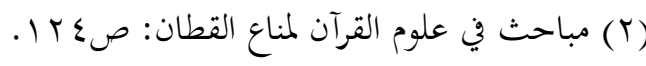

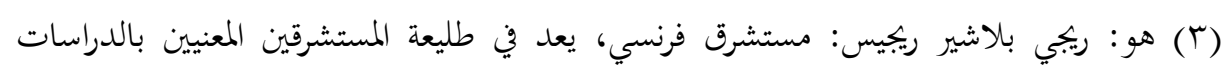

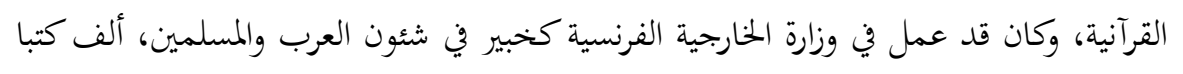

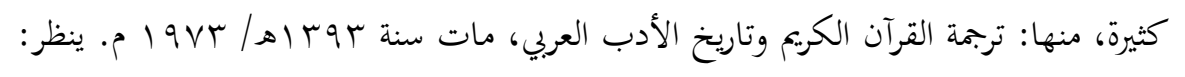

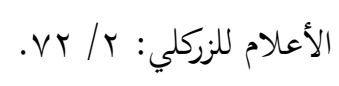

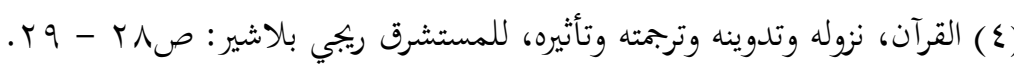

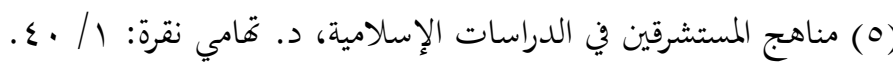




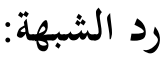

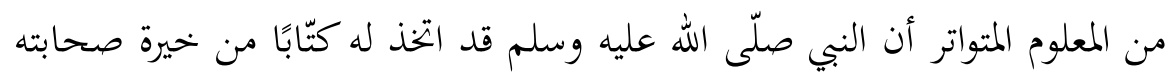

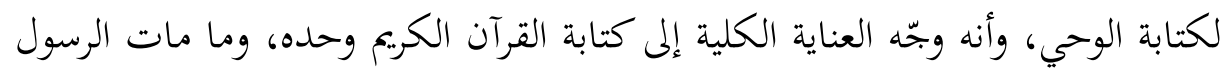

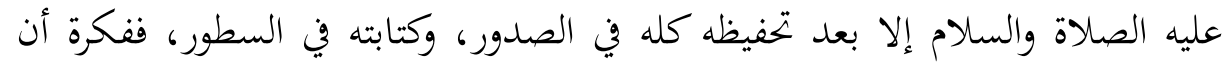

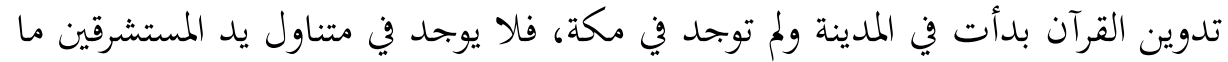

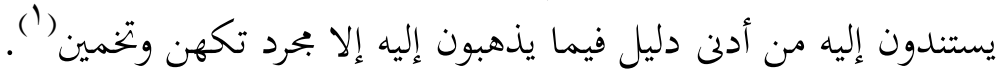

وإن حقائق التاريخ ووقائعه تؤكد مسايرة كتابة الوحي وحفظه في العهد المكي كما

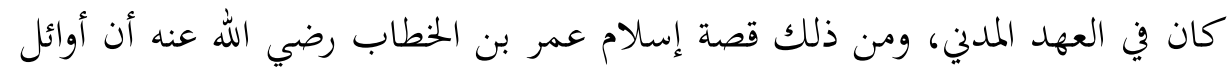

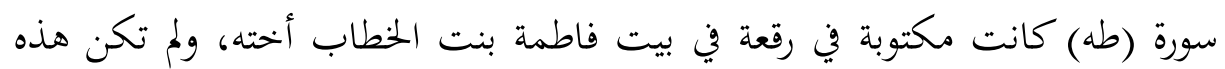

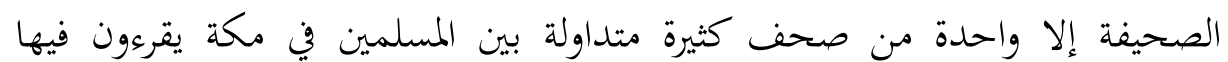

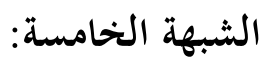

قال المستشرق جولدسيهر (r) في بداية بكثه في كتابه (مذاهب التفسير الإسلامي):

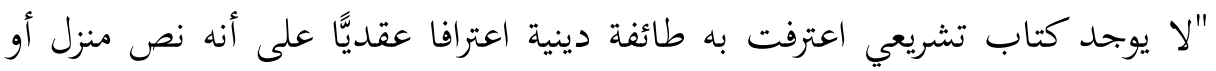

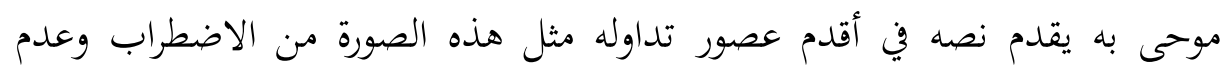
الثبات كما بنحد في النص القرآين" (").

$$
\text { (1) مناهج المستشرقين في الدراسات العربية الإسلامية: // ـ عـ. }
$$

(T) هو : أجناس جولدسيهر: مستشرق يهودي بحري، عرف بعدائه للإسلام وخطورة كتاباته عنه،

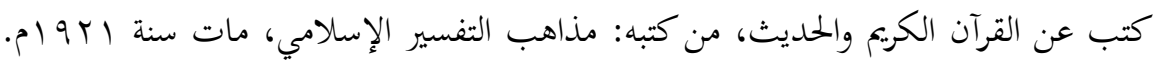

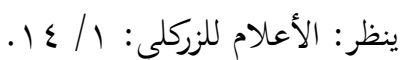

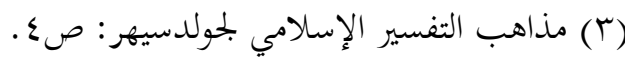




\section{رد الشبهة:}

ادّعاء جولدسيهر أن النص القرآي به اضطراب لم يوجد مثله في أي كتاب تشريعي آخر محض افتراء وقلب للحقائق، فأين رأى جولد سهر عن كتب الشرائع السابقة في نصوصها الأصلية حتى تصح له المقارنة والحكم على الاضطراب بالقرآن، فالتوراة والإنجيل والكتب المتداولة اليوم لدى اليهود والنصارى نسخ مختلفة ومرفة في نصوصها،

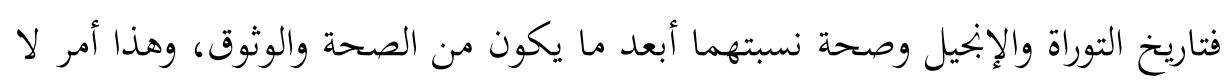
يخفى على المعنيين بدراستهما، بخلاف القرآن الذي لا يرقى إلى صحته شك كما قال

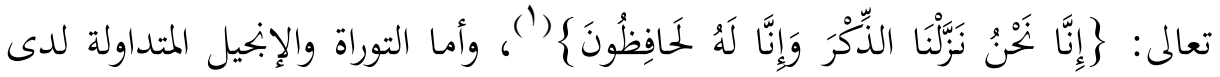
اليهود والنصارى فلا يشك في تحريفها أحد، والفضل ما شهدت به الأعداء، فهذا موريس بوكاي("أحأحد المستشرقين، ينتهي من المقارنة بين نص القرآن وبين نص التوراة والإنجيل إلى قوله: "صحة القرآن التي لا تقبل الجدل تعطي النص مكانة خاصة بين كتب التنزيل ولا يشترك مع نص القرآن في هذه الصحة لا العهد القديم ولا العهد

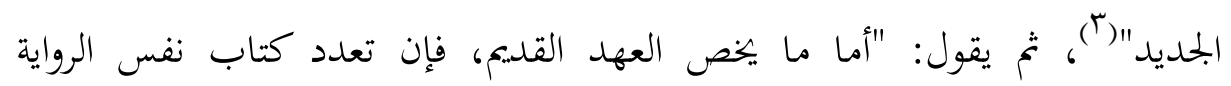
بالإضافة إلى تعدد المراجعات لبعض الكتب على عدة فترات قبل العصر المسيحي، هو

$$
\text { (1) سورة الحجر، الآية: } 9 .
$$

(Y) هو: موريس بوكاي، طبيب ومستشرق فرنسي، ولد سنة • ب9 1)، وكان الطبيب الشخصي

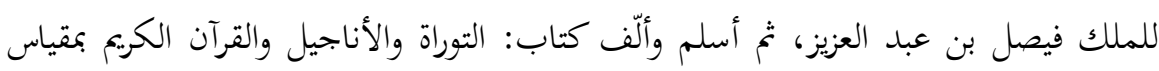

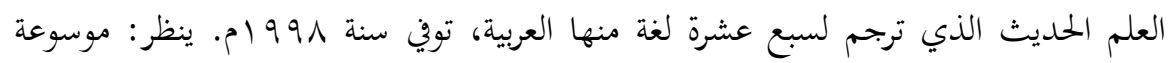

$$
\text { المستشرقين، عبد الرحمن بديوي، بو } 99 \text { ام. }
$$

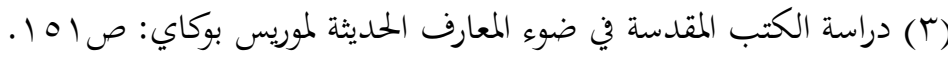


من أسباب الخطأ والتناقض، وأما فيما يخص الإنجيل، فلا يستطيع أحد أن يجزم أنها تحتوي على رواية أمينة لرسالة المسيح... ويختلف الأمر بالنسبة إلى القرآن، فهو فور

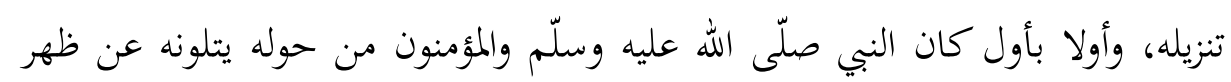
قلب، وكان الكتبة من صحبه يدونونه، إذا فالقرآن يتمتع منذ البداية بعنصري الصحة-

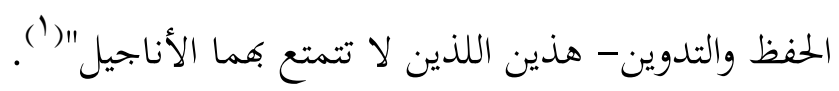

وما زعمه جولدسيهر من أن معنى الاضطراب وعدم الثبات في النص، هو أن النص

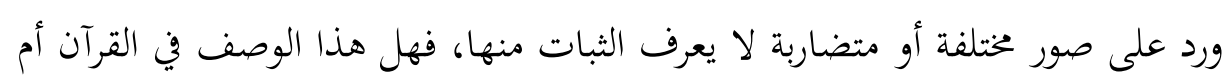
في التوراة والإنجيل المتداولة عند اليهود والنصارى؟ هل تحتوي التوراة والإنجيل نصا أمينا غير محرف وغير مضطرب؟

إها كلها محرفة وكلها مضطربة، أما القرآن الكريم فنصه موحد منذ نزوله على الرسول الكريم صلى الله عليه وسلم، وليس فيه شيء من الاضطراب البتة، أما القراءات

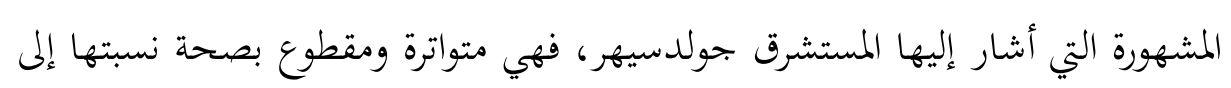

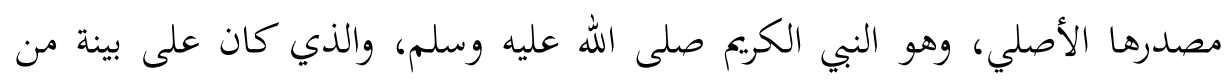

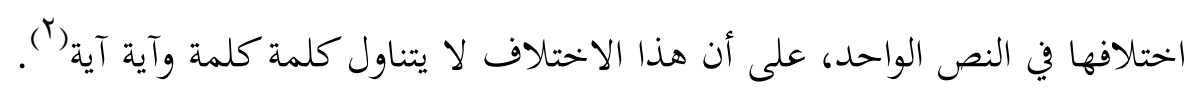

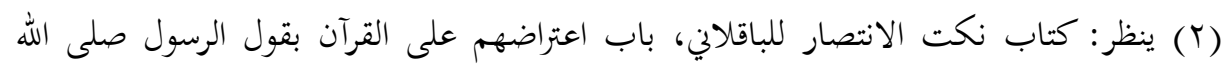

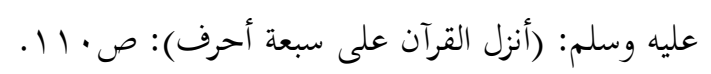


ثانيًا: الشبهات حول جمع القرآن في عهد أبي بكر الصديق رضي الله عنه

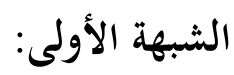

قال المستشرق هنري ماسيه('): (عند وفاة محمد لم يكن هناك أيّة بجموعة

للنصوص القرآنية فرزت بشكل غائي، وما من شك في أن عددا من بحموعة الوحي الأول لم تكن قد حفظت، ولكن شذرات هامة كانت قد سجلت كتابته على عظام

مسطحة وأوراق نخيل أو حجارة) (r).

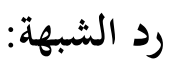

لقد تعود هؤلاء المستشرقون على إصدار أحكامهم حول الإسلام ورسوله وكتابه من

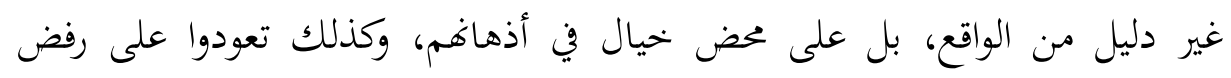
الأخبار والروايات الصحيحة ما دامت تأتي مناقضة لتلك الأحكام المسبقة، ومخيبة آمالهم في التشكيك في مصداقية الإسلام، وأنه دين الله اختاره للإنسانية جمعاء.

فهنري كغيره من المستشرقين يضرب عرض الحائط بتلك الأخبار التي تفيد بشكل

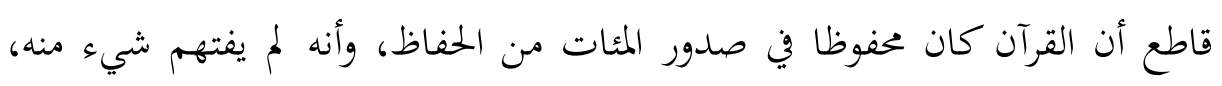

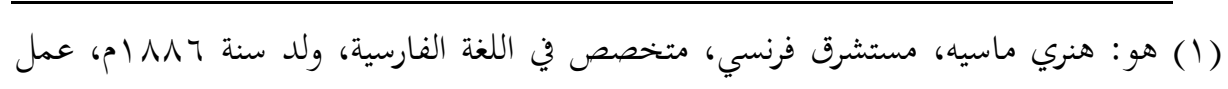

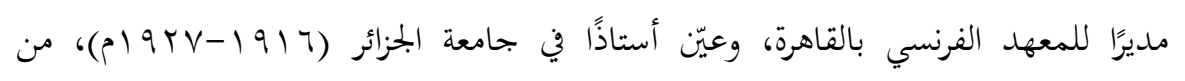

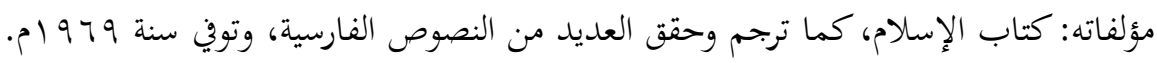

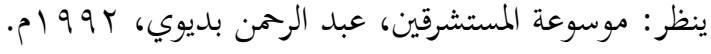

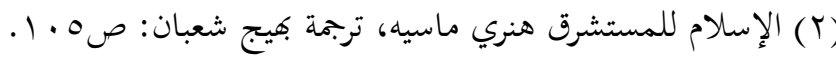




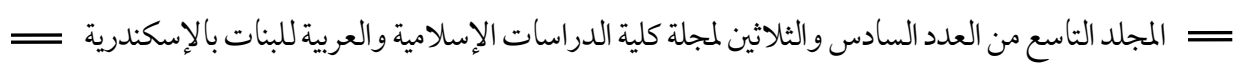
جمع القرآن ورد الشبهات حوله

والتي تؤكد كتابة القرآن كله في عهد الرسول صلى الله عليه وسلم، بل إن تلاوته كانت شغلهم الشاغل في الصلوات وغيرها، يتقربون بها إلى الله، وأن الرسول صلى الله عليه وسلم كان يبعث بالحفاظ لتعليمه خارج مكة والمدينة من المسلمين الجحدد؛ يقول الباقلاني: (إن الصدر الأول ومن بعدهم من المسلمين كانوا يعظمون القرآن تعظيما ما بعده من تعظيم، فكانوا يتقربون إلى الله بالعناية والحفظ له، فكيف يكون هذا موقفهم من القرآن، واهتمامهم به، وهم لا يحفظونه ولا يضبطونه، فكيف يصح ذلك وقد مكث الصحابة نيفا وعشرين سنة ينزل فيهم القرآن على النبي صلى الله عليه وسلم، وينقلونه عنه ويكضهمّ على حفظه، وقد ثبت في أحاديث كثيرة للنبي صلى الله عليه وسلم مبينا جزاء وثواب من تعلمه وحفظه وعمل به) (1).

ويدل على بطلان ما يدعونه من اضطراب نقل القرآن أو نقصه، أن جميع المسلمين في مشارق الأرض ومغاربها على مر الأزمان المختلفة، وهم جمعُ لا يجيوز على مثلهم التواطؤ أو التطابق على كذب؛ ينقلون أن القرآن الذي في مصاحفنا هو جميع القرآن الذي نزل على النبي صلى الله عليه وسلم. ويدل على صحة نقل القرآن الكريم قوله تعالى: $\}$ إِنَّا نَهْنُ نَزَنَنْا الذِّكُرْ وَإِنَّا لَهُ

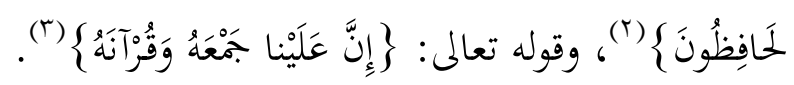

$$
\begin{aligned}
& \text { (1) الانتصار للباقلائ: ص آ - ب آT. } \\
& \text { (Y) سورة الحجر، الآية (9). } \\
& \text { (T) سورة القيامة، الآية (V (V). }
\end{aligned}
$$




\section{الشبهة الثانية:}

ادّعى المستشرق ريجي بلاشير أن جمع القرآن الذي بدأ في حياة أبي بكر لم ينته إلا

في عهد عمر، إذ كان قد بدأ قبل موت أبي بكر بخمسة عشر شهرًا، ميّا قد يؤثر على الثقة في تمام الجمع على الوجه المطلوب لاختلاف العصرين ')

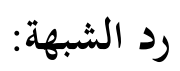

هذا الادّعاء غير مسلم به؛ لأن جمع القرآن قد تمّ في خلافة أبي بكر رضي الله عنه وبالتحديد بعد واقعة اليمامة، وقبل وفاة أبي بكر الصديق رضي الله عنه، هذا هو المتواتر عند جميع ناقلي السيرة وأهل الحديث بل وجميع المسلمين، وكانت العملية قد استمرت سنة واحدة في حياة أبي بكر رضي الله عنه، وليست خمسة عشر شهرا كما

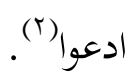

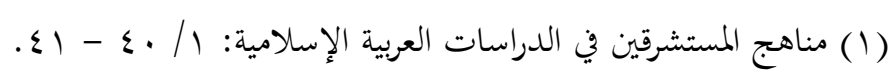

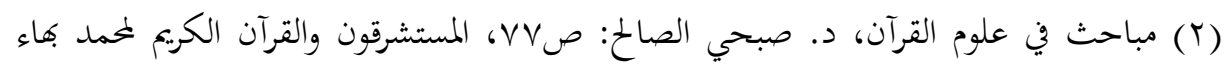
الدين: ص. م. مباحت 


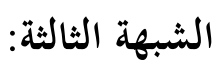

ادّعى المستشرق ريجي بلاشير أن جمع القرآن في مصحف واحد في عهد أبي بكر كانت ملكا خاصا لأبي بكر وعمر بصفتهما الشخصية، لا للخليفة رئيس الجماعة، ولقد دل كل شيء على أن الخليفة الأول وصاحبه حين أحسّا مغبة أن لا يكون لديهما نص كامل للوحي، كلفا أحد كتاب الوحي ممن سبق أن استخدمهم محمد في هذه الوظيفة بأن يهيئه لمما، فسبب جمع القرآن في عهدهما هو الرغبة في تملك نسخة شخصية من الوحي كما كان يملكها صحابة آخرون للنبي، فإن الأمر لم يكن في ذهن أبي بكر وعمر أمر فرض مصحف إمام على جماعة المؤمنين، وإنما يبدو أنه من المستحسن ألا يكون رئيس الجماعة في وضع أقل من بعض الصحابة من هم أحسن حالا، واستدلّوا على ذلك بأن حفصة رضي الله عنها ورثت هذا المصحف عن أبيها على أنه ذمة مالية شخصية (1).

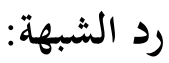

هذا الادّعاء حخض افتراء وينقضه انتقال المصحف بعد أبي بكر رضي الله عنه إلى عمر رضي الله عنه وليس بينهما توارث، فأبو بكر وعمر رضي الله عنهما لم يقوما بما قاما به معا إلا بدافع الإخلاص لكتاب الله تعالى والخشية عليه من أن يطرأ عليه ما يكدر صفاءه كما تلقاه المسلمون من فم رسول الله صلى الله عليه وسلم، وما أن (1) تاريخ القرآن، د. عبد الصبور شاهين: ص1 • 1، 9 • 1. 


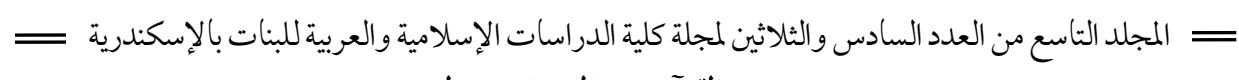
جمع القرآن ورد الثبهات حوله المراس الإلهات

انتهى زيد رضي الله عنه من جمعه لقي عمله استحسان ورضا جميع الصحابة وتواتر ما

إن الهدف من هذا الادعاء هو التقليل من قيمة العمل العظيم الذي أمر به أبو بكر رضي الله عنه، وبتحريده من كونه نتيجة جهود جبارة تضافرت بحتمعة فأفرزته، وبالتالي إضفاء الشخصية والمصلحة الذاتية عليه مما يجعله فاقدا لصفة التواتر المطلوبة في

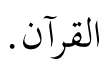




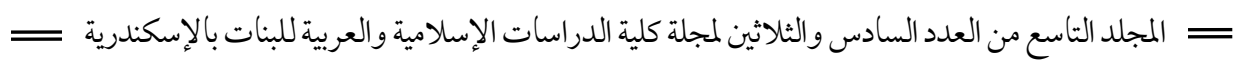
جمع القرآن ورد الشبهات حوله

ثالثًا: الشبهات حول جمع القرآن في عهد عثمان بن عفان رضي الله عنه

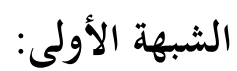

زعم المستشرق هنري ماسيه أن المصحف الذي أمر عثمان رضي الله عنه بجمعه لا

يتضمن الوحي كله، وبأنه قد أضيفت إليه بعض الإضافات التفسيرية والتذييلات، مع الته

تغيير أماكن بعض الجمل (1).

رد الشبهة:

هذا الكلام بحرد دعوى بدون دليل، ولو كان هذا المستشرق صادقا في ادّعائه لأتى

بدليل أو وضع يده على بعض تلك الإضافات التي ضُمّت إلى القرآن، وسكت عنها

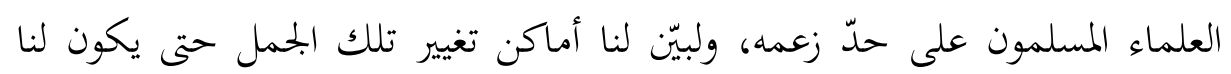
موقف من مناقشته على ضوء ذلك. أما إطلاقه الكلام من غير تبيان، فيعدّ خلافًا

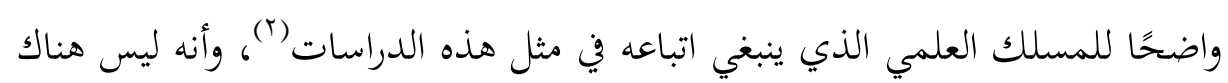

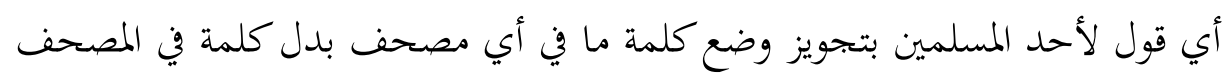
العثماني المنسوخ قطعًا عن مصحف أبي بكر المأثور يقينا عن النبي صلى الله عليه

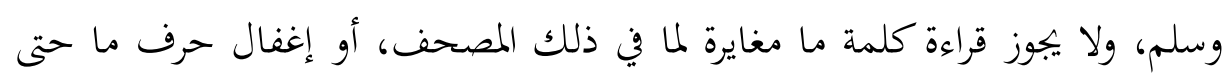

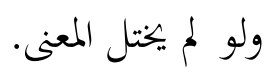

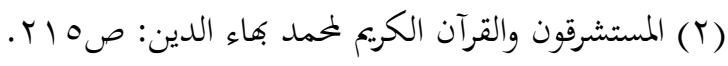




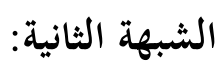

زعم المستشرق ريجي بلاشير أن هذا المصحف فرضه عثمان رضي الله عنه على المسلمين فرضًا، وقد واجه مقاومة من بعض الصحابة تمّ القضاء عليها بالقوة (1).

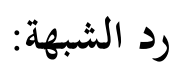

من المعروف أن الخليفة عثمان بن عفان رضي الله عنه عندما انتهى من جمع القرآن في مصحف واحد، أمر بإحراق كل القطع والمصاحف التي كتب فيها القرآن من لدن

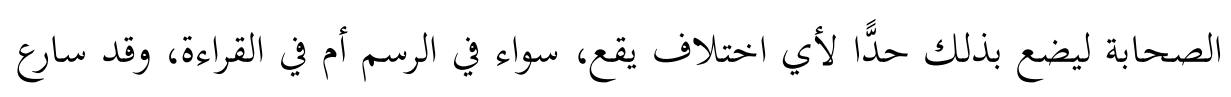

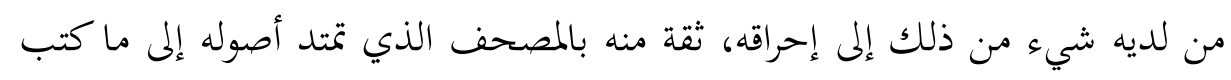

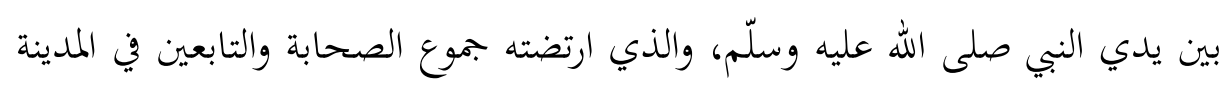
وغيرها من الأمصار. ولم يتخلف عن ذلك -في بادئ الأمر - إلا عبد الله بن مسعود رضي الله عنه، ومن تبعه من أهل الكوفة(؟). ولا بحال للشك في أن ابن مسعود رضي الله عنه قد رجع بعد زوال الغضب عنه إلى الحق، وعلم حسن اختيار عثمان رضي الله عنه ومن معه من أصحاب رسول الله

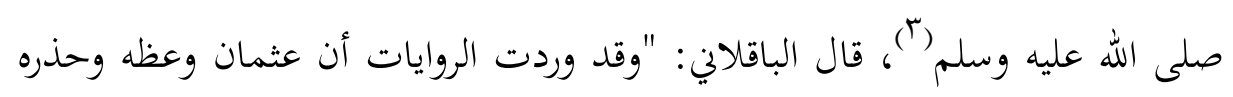

$$
\begin{aligned}
& \text { (1) كتاب القرآن لرييمي بلاشير: صع ب. }
\end{aligned}
$$

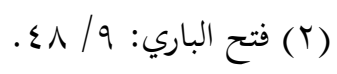

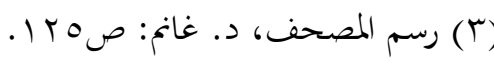




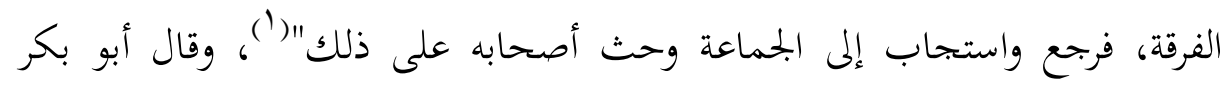
الأنباري: "وما بدا من عبد الله بن مسعود من نكير ذلك فشيء نتيجة الغضب ولا

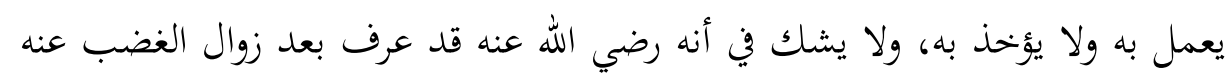

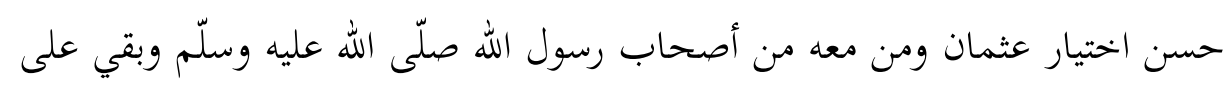
موافقتهم وترك الخلاف لهم" (؟).

يقول الدكتور عبد الله دراز: "نظرا لغيرة المسلمين الأوائل وهم بطبيعة الحال أكثر

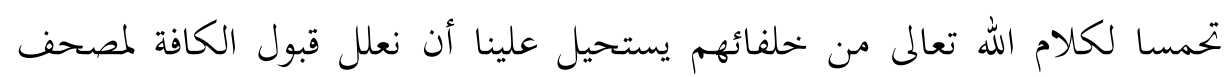

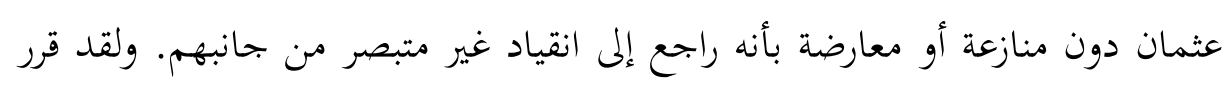

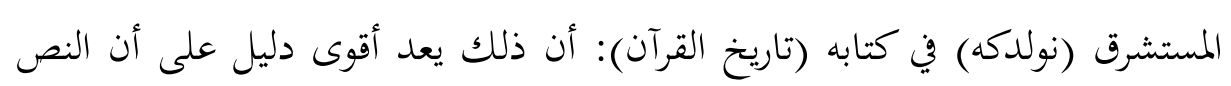

$$
\text { القرآني على أحسن صورة من الكمال والمطابقة"("). }
$$

وقال الآمدي: "إن المصاحف المشهورة في زمن الصحابة كانت مقروءة عليه صلّى

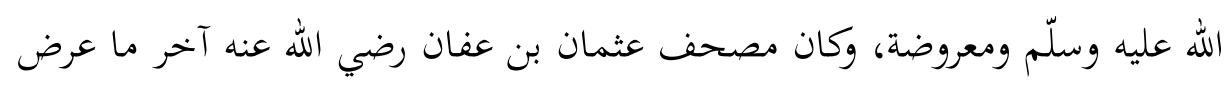
على النبي صلى الله عليه وسلم وكان يصلي به إلى أن قبض "((ء).

$$
\begin{aligned}
& \text { (1) نكت الانتصار للباقلاني: صع ب؟r. }
\end{aligned}
$$

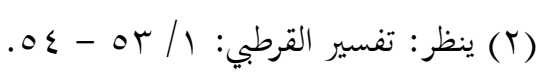

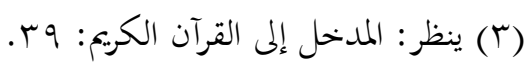

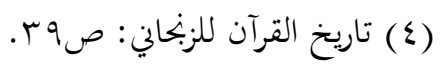




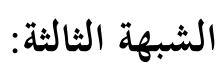

ادعى لويس جارديه(')، والأب قنواتي(") في كتابيهما (فلسفة الفكر الديني بين

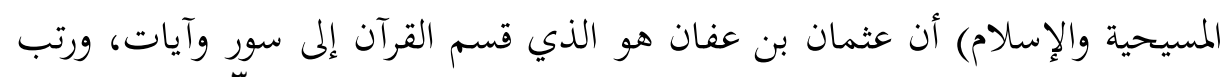

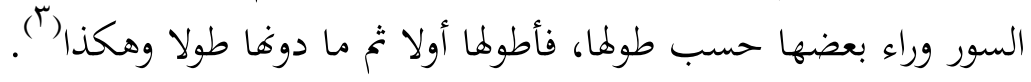

وقال المستشرق ريجرد بيل: "إن الترتيب الحالي والمعروف لدى المسلمين ترتيب

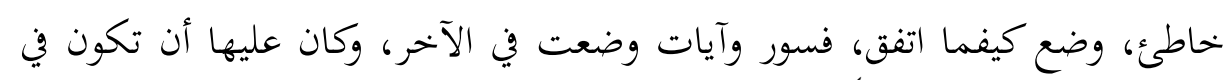

$$
\text { الأول، والعكس صحيح" (ع). }
$$

هذه الادعاءات مخض افتراءات ومزاعم مخالفة للحقيقة والواقع، وليس هناك أدنى

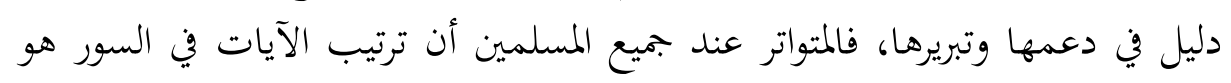
بتوقيف من النبي صلّى الله عليه وسلم، وبتوجيه من الوحي.

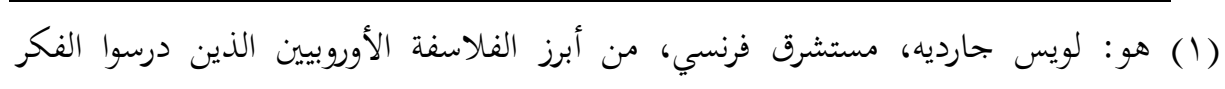

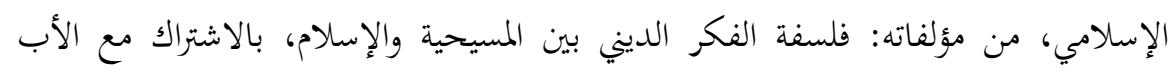

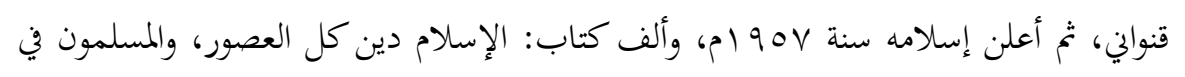

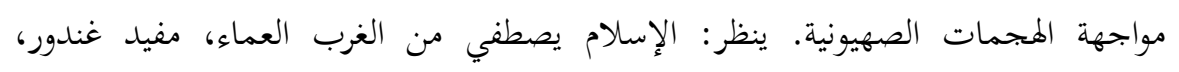
صa

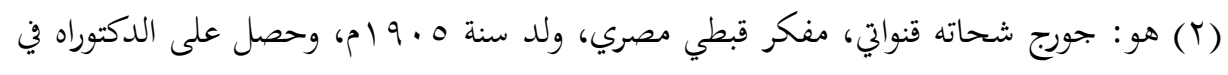

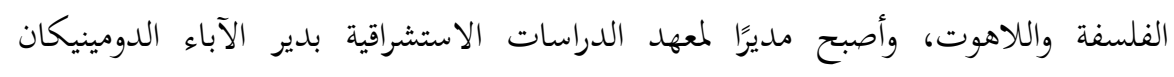

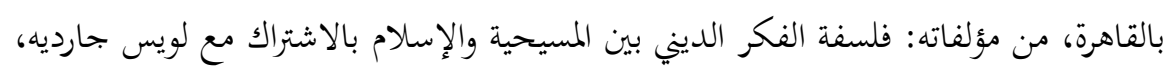

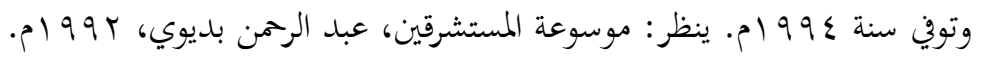

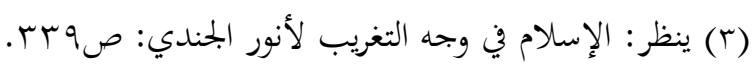

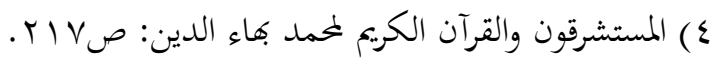




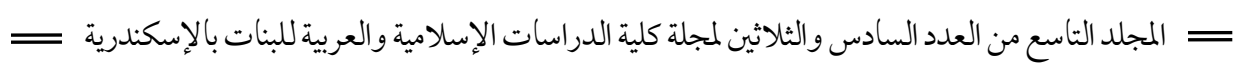
جمع القرآن ورد الشبهات حوله

إن ترتيب الآيات في السور بهذا الشكل العجيب البديع، وبهذا الترابط بين الآيات

بعضها ببعض، والذي يبدو لمتأمله وكأفا حلقات مترابطة في سلسلة من ناحية اللفظ والمعنى فيه، فيجد الترابط والتلاحم التامين بين الآية وسابقتها ولاحقتها. على الرغم من أن هذه الآيات كان نزولها متفرقا، واستمر أكثر من عشرين عاما، فترتيب الآيات إنما

$$
\text { هو وجهه آخر من وجوه الإعجاز القرآني (') }
$$

فالمصحف المتداول اليوم الذي هو مرتب على وفق ترتيب النبي صلّى الله عليه وسلم لآياته وسوره، وكذلك فإن التواتر لم ينقطع بين المسلمين على أن هذه المصاحف المتداولة اليوم إنما هي نسخة طبق الأصل في النص والترتيب لتلك المصاحف العثمانية التي تم نسخها بأمر من الخليفة الراشد عثمان بن عفان رضي الله عنه، وتلك المصاحف العثمانية قد تم نسخها نصا وترتيبا عن المصحف المحرر زمن الخليفة الراشد الأول أبي بكر الصديق رضي الله عنه على ملأ من أصحاب رسول الله صلّى الله عليه وسلم، والذي اشتمل على كل ما ثبت أنه قرآن غير مرفوع وغير منسوخ التلاوة حين وفاة الرسول صلى الله عليه وسلم (r).

(1) تاريخ القرآن، د. عبد الصبور شاهين: صه العان 11 .

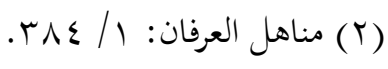




\section{الخاتمة}

الحمد لله الذي بنعمته تتم الصالحات، والصلاة والسلام على سيدنا محمد وعلى

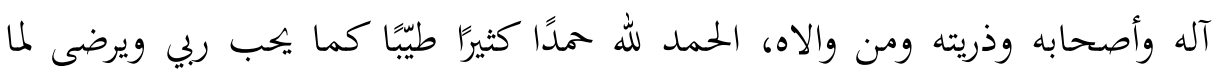

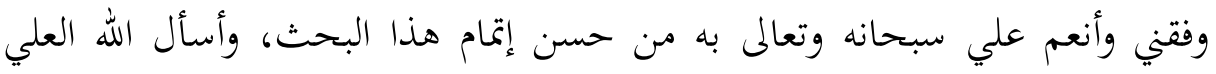

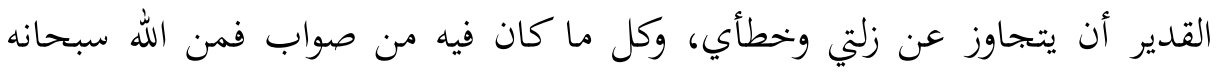
وتعالى، وما فيه من خطأ فمن نفسي ومن الشيطان.

\section{ومن أهم النتائج التي توصلت إليها:}

1 - جمع القرآن نوعان: جمع في الصدور وهو الحفظ، و.مع في السطور وهو الكتابة. ب - كان النبي صلى الله عليه وسلم يقرأ القرآن لبعض صحابته، ويهتم بأن يجفظوه. ب- الاعتمـاد في نقل القرآن الكريم كان على حفظ القلوب والصـدور لا على حفظ المصاحف والكتب، وهو ما يعد أشرف خصيصة من الله تعالى لهذه الأمة. ع - كان النبي صلى الله عليه وسلم يأمر بكتابة ما ينزل عليه من القرآن فور نزوله. هـ كان القرآن كله مكتوبًا في عهد النبي صلى الله عليه وسلم ولكنه لم يكن بحموعًا في مصحف واحد.

ج- أشـار عمر رضي الله عنه على أبي بكر الصديق رضي الله عنه بأن يجمع القـرآن لئلا يذهب بسبب موت من يحفظه من الصحابة في مواطن القتال. V- كلّف أبو بكر الصديق رضي الله عنه لمهمة جمع القرآن زيد بن ثابت رضي الله عنه؛ لأن فيه خصالًا لم بحتمع في غيره: كونه شابا، فيكون أنشط لما يطلب منه، 


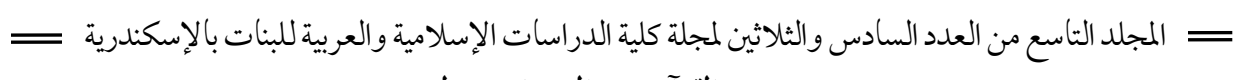
جمع القرآن ورد الشبهات حوله

وكونه مـن كتبـة الوحي على عهـد رسول الله صلى الله عليه وسـلم وحضـر الختمـة الأخيرة التي ختمها النبي صلى الله عليه وسلم قبل موته مع جبريل عليه السلام. ^- في عهـد عثمـان بـن عفـان رضـي الله عنـه اتسعت الفتوحـات الإسـلامية، وسمـح عثمـان للصـحابة أن ينتشـروا في الأمصـار، فتفرق القراء مـنهم في الأمصـار، وأخــ أهل كل مصر عن من وفد إليهم من القرّاء، ووجوه القراءات التي يؤدّون بها القرآن مختلفة باختلاف الأحرف التي نزل بها القرآن الكريم، فأدّى ذلك لنشوء الاختلاف بينهم الذي كان ينذر بوقوع الفتنة في عموم الأمـة؛ لذلك شرع عثمان رضي الله عنه في توحيد المصاحف على مصحف واحسد يقرؤه جميع المسلمين بـلا اختلاف بينهم.

و- لجنة جمع القرآن التي قامت بهذه المهمة في عهد عثمان بن عفان رضي الله عنه كانـت تتكـون مـن زيــ بـن ثابـت رئيسًا، ومعـه ثلاثنة مـن شباب قريش، فكـانوا يكتبون القرآن نسخا وإذا اختلفوا في موضع الكتابة على أي لغة، رجعوا إلى عثمان رضي الله عنه. • إ عنــما انتهـت اللجنـة التي كوهـا عثمـان بـن عفـان رضـي الله عنسه مـن نسـخ المصاحف، أرسل إلى كل أفق من الأقطار بمصحف منا نسخوا، وأمر أن يحرق كل ما عداها مما يخالفها. 11 - لم يستبدّ عثمان رضي الله عنه برأيه في هذا الأمر الجليل، بـل مـا أقدم عليه إلا

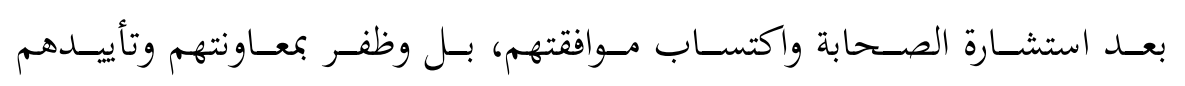
وشكرهم. 


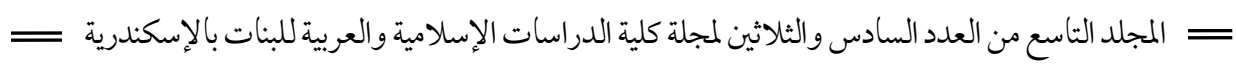
جمع القرآن ورد الشبهات حوله المرات الإلادية

r ا - كان القرآن الكريم ولا يزال هدفا لأعداء الإسلام، يسددون إليه سهام المطاعن، ويتخذون من علومه مثارا للشبهات، يلفقوها زورا وكذبا.

r ا - انتشرت في العصر الحديث شبهات المستشرقين خاصة حول جمع القرآن. ع ا - المقصود بالاستشراق هو : دراسة غير الشرقيين لحضارات الشرق وأديانه ولغاته وتاريخه وعلومه واتحاهاته النفسية وأحواله الاجتماعية، ولا سيما الحضارة الإسلامية وأحوال المسلمين في مختلف العصور. 1 - الاستشراق كان وما يزال جزءا لا يتجزأ مـن قضية الصراع الحضـاري بين العالم الإسلامي والعالم الغربي. 7 ا 1 - إن الله تعالى وعد نبيه صلى الله عليه وسلم أن يقرأه القرآن فلا ينسى شيئًا منه إلا ما شاءه؛ وهو ما نسخت تلاوته لحكمة من الحِكَم.

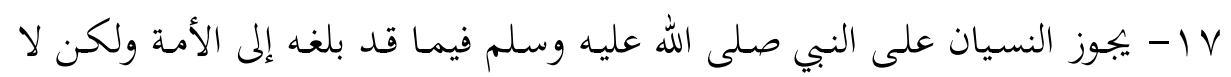
يستمر ذلك النسيان بل يكصل له تذكرة إما بنفسه وإما بغيره. 1 - - لم يجمع القرآن في مصحف واحد زمن النبي صلّى الله عليه وسلّم لماكان يترقبه عليه الصلاة والسلام من ورود ناسخ لبعض أحكامه أو تلاوته. 9 ا - حقائق التاريخ ووقائعه تؤكد مسايرة كتابة الوحي وحفظه في العهد المكي كما

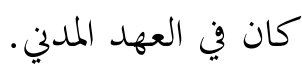
• r- جمع القرآن في مصحف واحد قد تمّ في خلافة أبي بكر الصديق رضي الله عنه بعد واقعة اليمامة، واستمرت العملية سنة واحدة وانتهت قبل وفاة أبي بكر رضي الله عنه. 


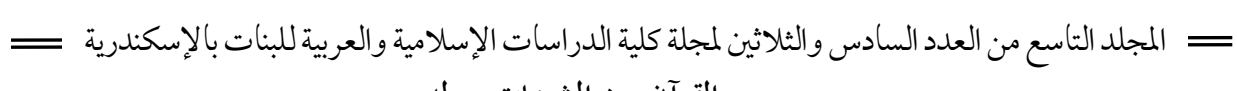
جمع القرآن ورد الشبهات حوله

ا Y- كان مصحف عثمان بن عفان رضي الله عنه بترتيبه المحفوظ إلى عصرنا هذا هو آخر ما عرض على النبي صلى الله عليه وسلم وكان يصلي به إلى أن قبض. Y Y - أجمع المسلمون على مرّ العصور على أن المصحف الذي جمعه عثمان بن عفان رضي الله عنه لم ينقص منه حرفًا مما نزل على رسول الله صلى الله عليه وسلم من الوحي، وكذلك لا يوجد فيه حرفًا زائًا عما نزل من الوحي.

rr - المتواتر عند جميع المسلمين أن ترتيب الآيات والسور في المصحف العثماني هو بتوقيف من النبي صلّى الله عليه وسلم، وبتوجيه من الوحي.

\section{الثوصيات:}

ا - لا يتوقف المستشرقون على مرّ العصور عن تلفيق الشبهات للقرآن، لذلك نوصي بأن تكون هناك الجان متخصّصة لرد جميع الشبهات التي يستحدثها المستشرقون حول القرآن الكريم أوَّاًا بأول. ץ - لابد من الاهتمام بدوام التواتر الإسنادي لنقل القرآن الكريم، ولا يُكتفى بوجود الحفّاظ وطباعة المصاحف، لذلك نوصي بإنشاء هيئة علميّة تضمّ أكابر قرّاء القرآن الذين يجمعون القراءات المتواترة بالأسانيد الصحيحة إلى النبي صلى الله عليه وسلم في مختلف أقطار الإسلام، وتكون من مهام هذه الهيئة الإشراف على أسانيد القرآن المحفوظة، ومنح الإجازات لحفاظ القرآن بالقراءات المختلفة بالأسانيد الصحيحة إلى النبي صلى الله عليه وسلم. 


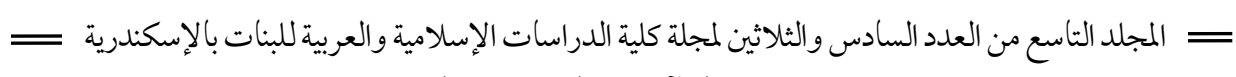

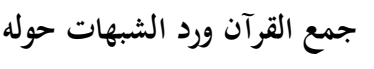

ب- الجامعات هي حاضنة العلم والعلماء في العصر الحديث؛ لذلك نوصي باعتماد

مادة في مرحلة البكالوريوس للأقسام الشرعية بمقرر يُعنى بالدفاع عن القرآن ورد الشبهات حوله ومنها الشبهات حول حفظه وجمعه.

ك - بحالس الذكر والدعوة في المساجد لما دور لا يغفل في توجيه المحتمع؛ لذلك نوصي بإعداد حملات دعوية توعوية للذبّ عن القرآن الكريم وبيان فساد الشبهات التي تثار حوله إلى عموم المسلمين حتى لا يكونوا عرضة للوقوع في شراك هؤلاء المستشرقين خاصة مع انتشار وسائل التواصل الحلديثة وسهولة الاطلاع على جميع الأفكار والآراء الصحيحة والباطلة بضغطة زر على الحاسوب أو الجوال. 


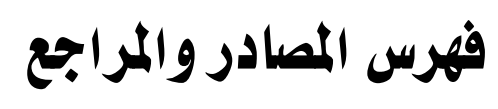

1- الإتقان في علوم القرآن: الإمام العلامة أبي الفضل جلال الدين عبد الرحمن أبي

بكر السيوطي الشافعي (ت: 11 (1)هـ، دار الكتب العلمية، بيروت، لبنان.

r - الاستشراق والتبشير قراءة تاريخية موجزة: للدكتور سيد الجليند، دار قباء بالقاهرة

$\cdot($ ( 1999$)$

ب- الاستيعاب في معرفة الأصسحاب: لابـن عبـد البر أبي عمـر يوسف بـن عبـد الله

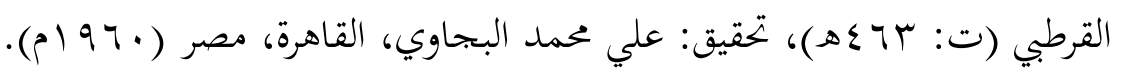

ع- الإسلام في وجه التغريب: أنور الجندي، دار الاعتصام، القاهرة.

0- الإسلام، هنري ماسيه، ترجمها: بهيج شعبان، منشورات عويدات، بيروت، لبنان.

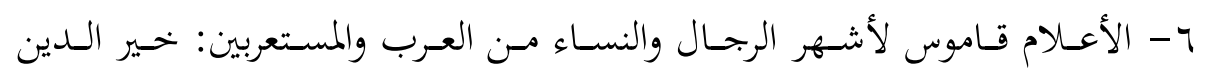

الزركلي، ط ؟، دار العلم للمايين، بيروت.

V- الانتصـار لصحة نقـل القـرآن والكرد على مـن نحلـه الفسـاد بزيـادة أو نقصـان:

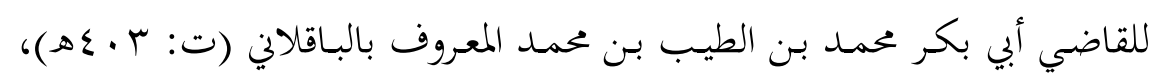

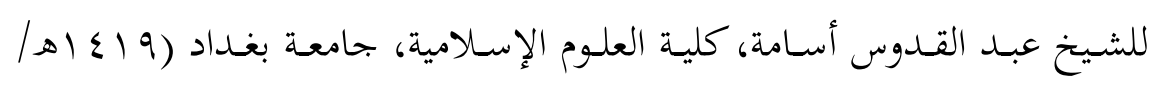

$\cdot($ ( ) 991

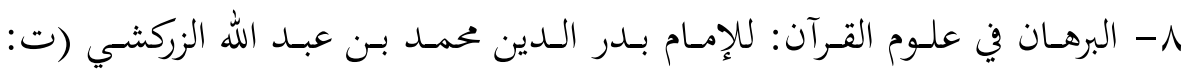

§ צاهـ)، تحقيق: محمد أبو الفضل إبراهيم، دار التراث، القاهرة.

و- تاريخ الرسل والملوك (تاريخ الطبري): لأبي جعفر محمد بن جرير الطبري (ت:

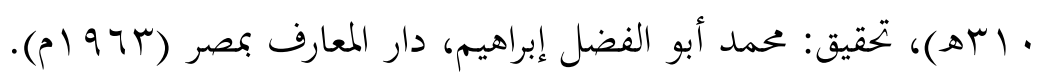

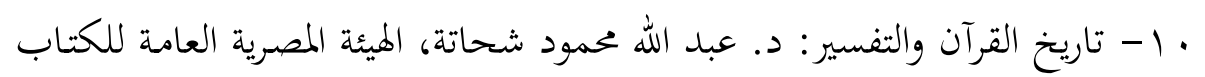

(b) ( $9 V T / D / T Q T)$ 


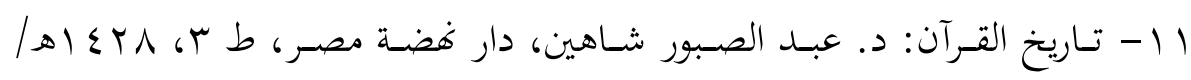

$$
\text { . }
$$

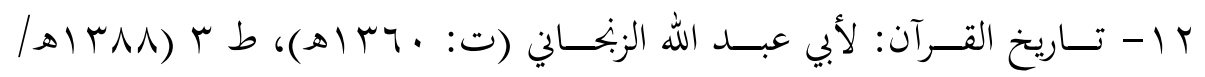

979 (1)، 97 (منشورات مؤسسة الأعلمي للمطبوعات، بيروت، لبنان.

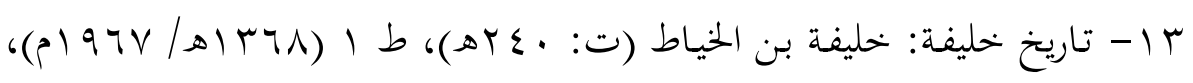

مطبعة الآداب في النجف، ساعد البحمع العلمي العراقي على نشره.

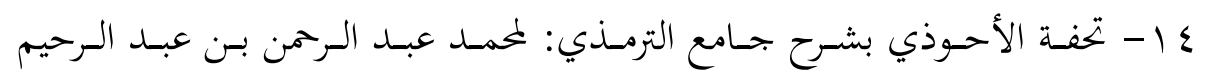

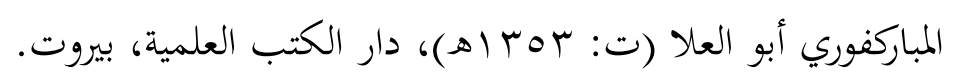

$$
\text { } 1 \text { - تفسير المنار: محمد رشيد رضا، دار المعرفة، بيروت. }
$$

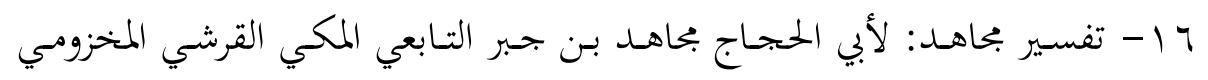

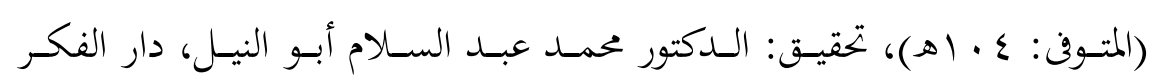

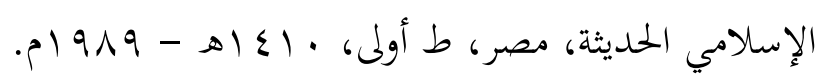

IV

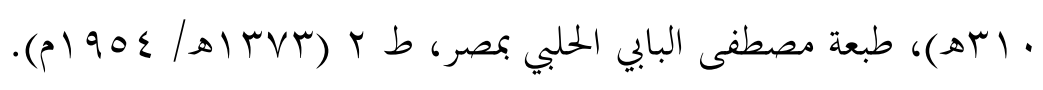

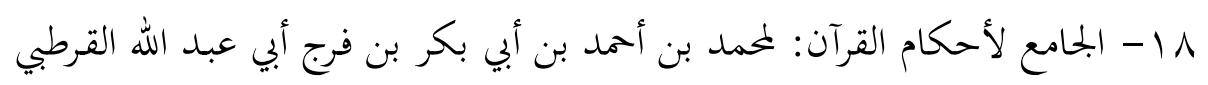

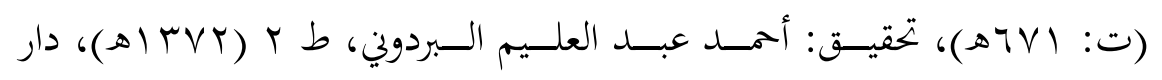

$$
\text { الشعب، القاهرة. }
$$

9 1 - حلية الأولياء وطبقات الأصفياء: لأبي نعيم أحمد بن عبد الله الأصفهاني (ت:

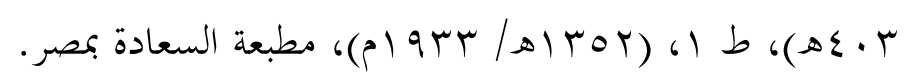

• ب- دائرة المعارف الإسلامية، فؤاد أفرام البستاني، وبحموعـة مـ المستشرقين، نقلها

$$
\text { إلى العربية: محمد ثابت، طبعة طهران. }
$$

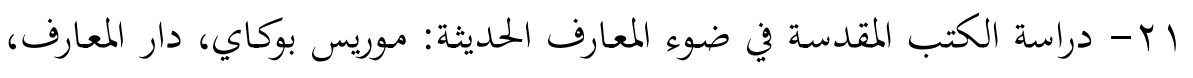




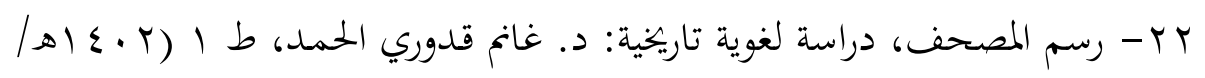

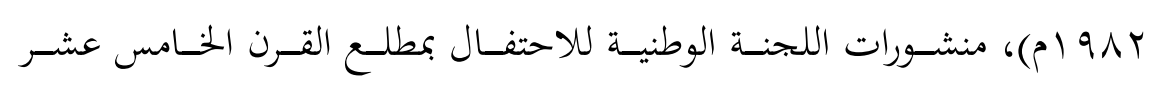

$$
\text { الهجري، بغداد. }
$$

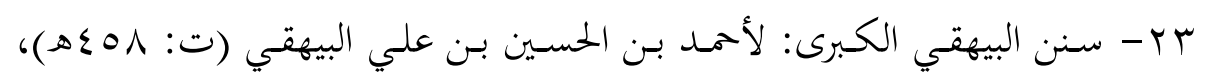

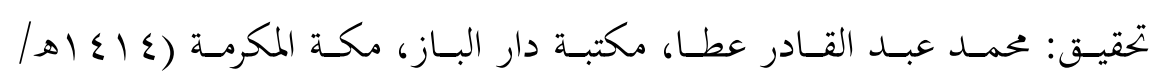
$\cdot($ ) $199 \varepsilon$

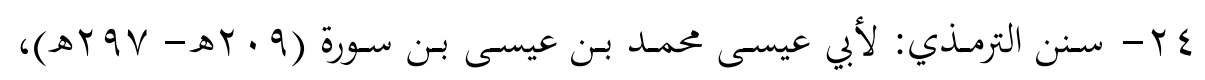
تحقيق وشرح: أحمد محمد شاكر، دار الكتب العلمية، بيروت، لبنان.

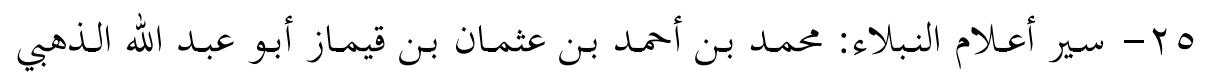

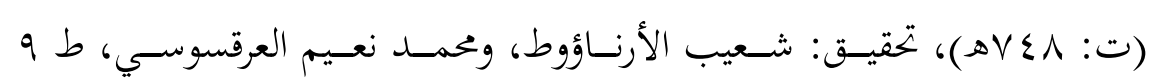
(r)

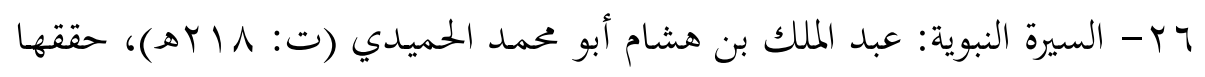

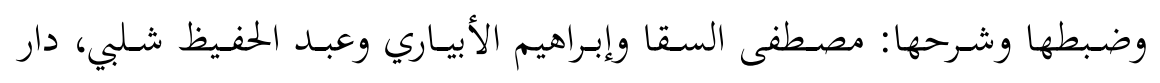
القلم، بيروت، لبنان.

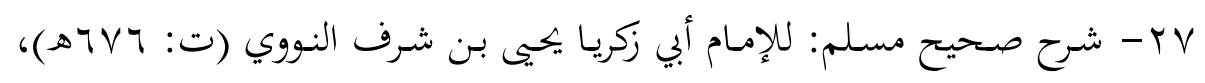

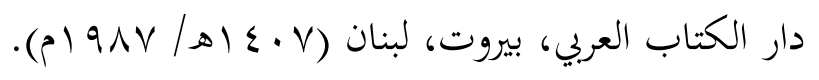

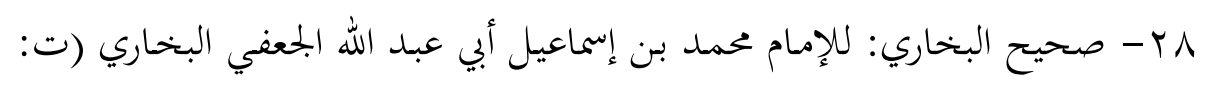

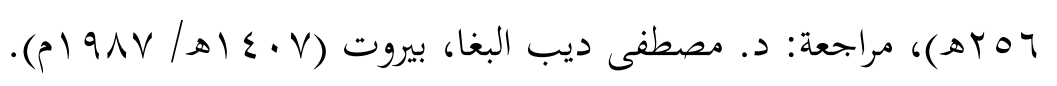

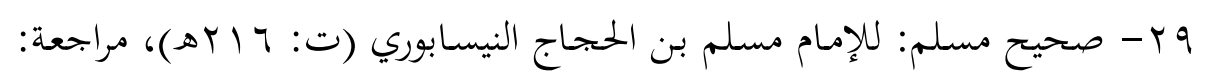

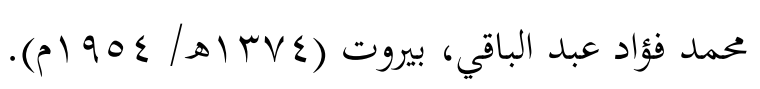

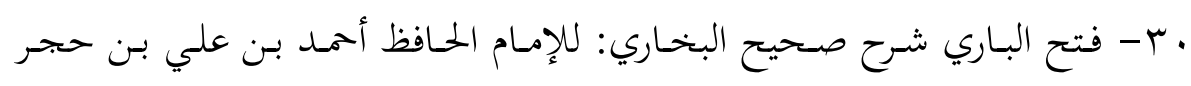

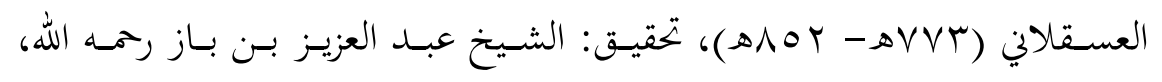

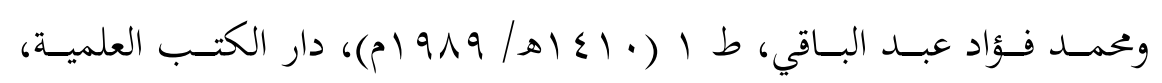
بيروت، لبنان. 
اب- فضائل القرآن: للإمام الحافظ عماد الدين أبي الفداء إسماعيل بن كثير القريشي

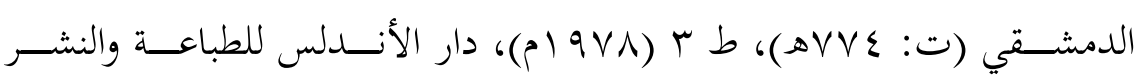

والتوزيع، بيروت.

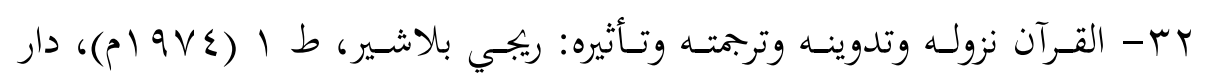

الكتاب اللبناني، بيروت. البرت

بr- الكلمـات الحسـان في الحـروف السـبعة وجمـع القـرآن، تـأليف: العلامـة الشسيخ

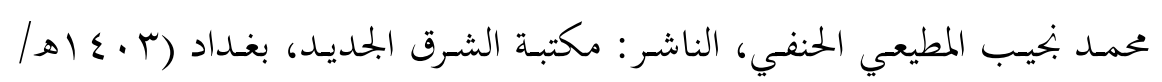
$\cdot(b) q \Lambda t$

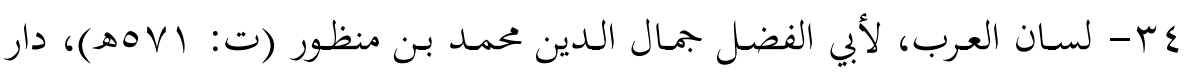

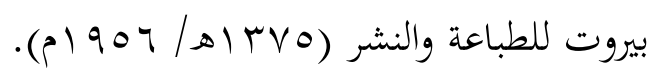

هب- مباحث في علوم القرآن: للدكتور صبحي الصالح، ط ع (1970 ام)، دار العلم

للملايين، بيروت.

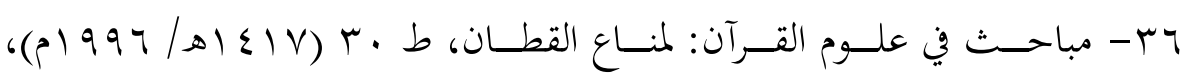

مؤسسة الرسالة، بيروت.

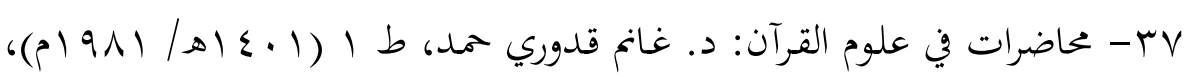
دار الكتاب للطباعة، بغداد.

^ب- مختـار الصحاح: محمـد بـن أبي بكر بـن عبـد القـادر الرازي (ت: 7 7هـ)، دار

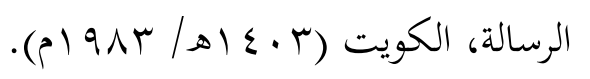

وب- مدخل إلى القرآن الكريم- عرض تاريخي وتحليل مقارن: د. محمد عبد الله دراز،

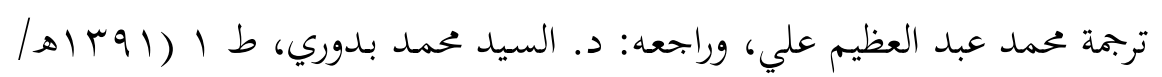

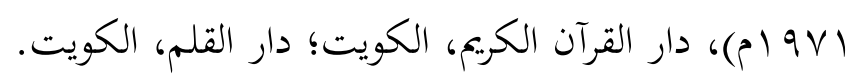

• ع - مذاهب التفسير الإسلامي: أجنتس جولد تسيهر، ترجمة الدكتور عبد الحليم

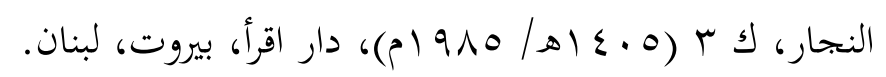


اء - المرشد الوجيز في علوم تتعلق بالكتاب العزيز: تأليف شهاب الدين عبد الرحمن

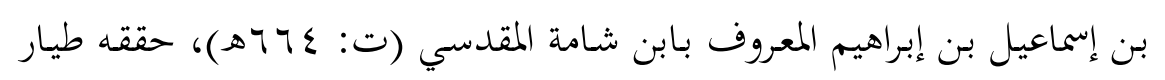

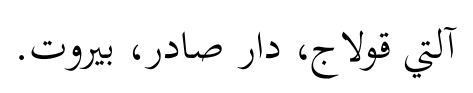

r

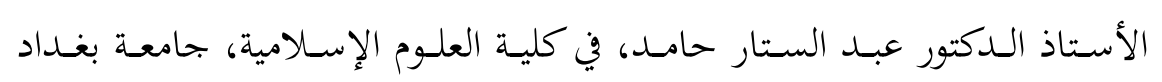

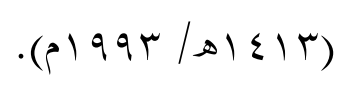

rع - مسند الإمام أحمد بن محمد بن حنبل (ت: إع آه)، القاهرة، مؤسسة قرطبة.

§ - المصاحف: لأبي عبد الله بن أبي داود سليمان بن الأشعث السجستاني (ت:

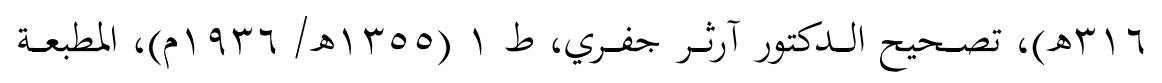
الرحمانية، مصر؛ أعادت طبعه بالأوفسيت مكتبة المثنى، بغداد.

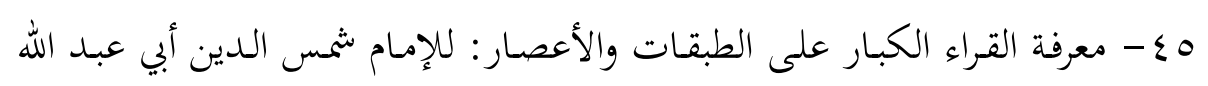

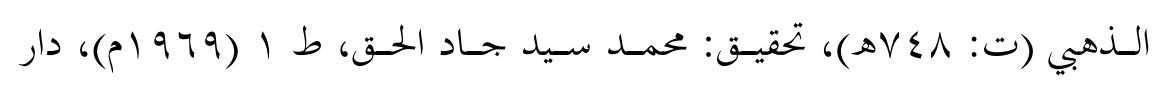

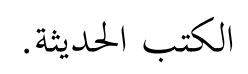

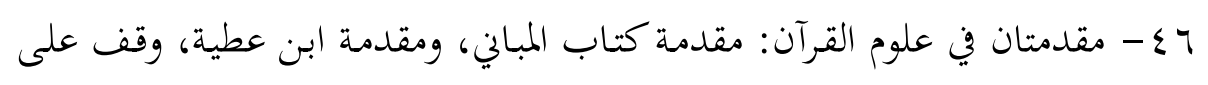

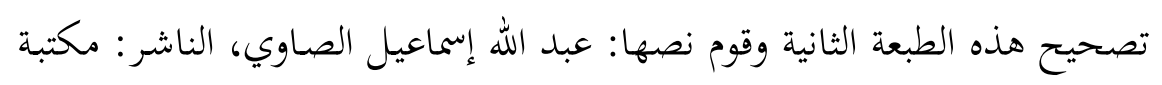

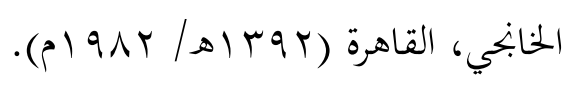

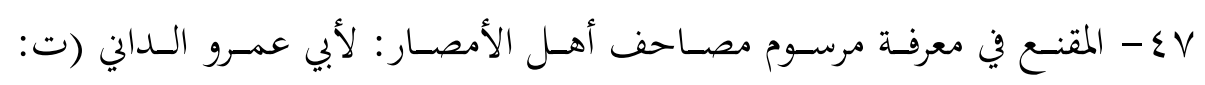

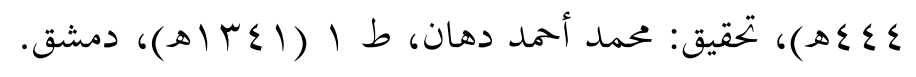

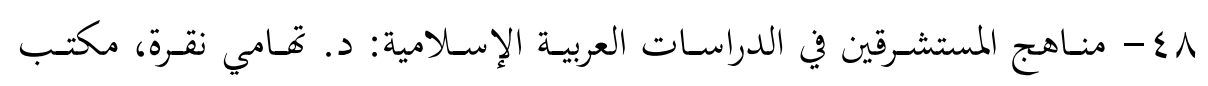

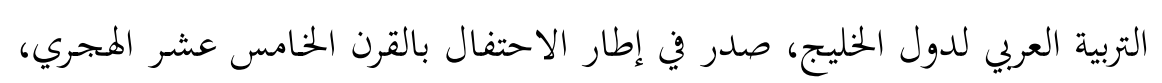
السعودية، الرياض.

9 - - منــاهج المستشـرقين: د. سـعدون السـاموك، ود. عبــد القهـار العـاني، كليـة

الشريعة، جامعة بغداد (919 اجم).

• هـ - مناهل العرفان في علوم القرآن: لمحمد بن عبد العظيم الزرقاني، دار الفكر. 


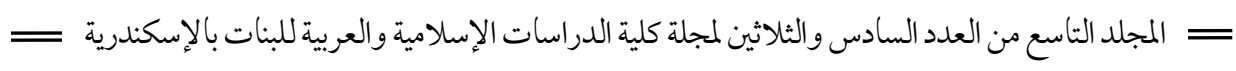

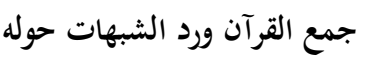

|0- منهجية البحث الاستشراقي: د. سعدون محمود الساموك، بغداد (991 ام). ror- النشر في القراءات العشر: للحافظ أبي الخير محمد بن محمد الدمشقي الشهير بـابن الجـوزي (ت: بrمهـ)، أشـرف على تصححيحه ومراجعتـه للمـرة الأخهيرة:

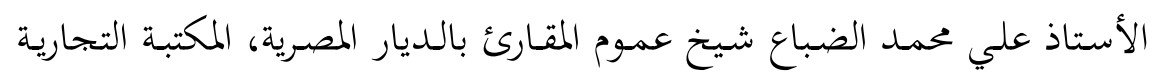
الكبرى، شارع محمد علي، أعادت طبعه بالأوفسيت مكتبة المثنى، بغداد. 